
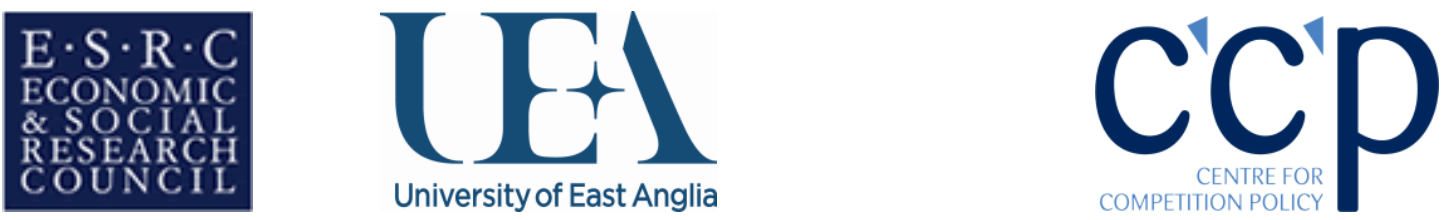

\title{
Myths and Untold Stories - Private Antitrust Enforcement in Germany
}

\author{
Sebastian Peyer* \\ *Doctoral Candidate at the ESRC Centre for Competition Policy \& Norwich \\ Law School, University of East Anglia
}

CCP Working Paper 10-12

\begin{abstract}
:
The paper offers an empirical analysis of private antitrust enforcement in Germany based on cases that were decided by courts between 2005 and 2007 . The study presents information about the magnitude and nature of civil antitrust actions in Germany. The data includes inter alia, information about the courts involved in litigation, the relationship of the parties, affected industries, the remedies sought, the outcome of the claim, the alleged anticompetitive conduct, the proportion of stand-alone and followon litigation, and the length of proceedings before a given court. The study shows that a large number of private cases were concluded even when compared with public investigations in Germany. It seems that private antitrust actions complement rather than duplicate public enforcement efforts because of the overwhelming proportion of stand-alone claims and the amount of actions based on the abuse of market power. Only a small number of litigants asked for the compensation of loss suffered from anticompetitive conduct. Interpreting the results from the study cautiously, the paper suggests that the European Commission and other stakeholders may have misunderstood the nature of private actions in Germany (and maybe Europe) and, consequently, asked the wrong question, focusing on compensation. Expensive damages actions for the breach of the antitrust rules might not be as important as commonly assumed.

July 2010
\end{abstract}


JEL Classification Codes: K21, K42.

Keywords: Private antitrust enforcement; White Paper; Empirical study; Germany.

\section{Acknowledgements:}

The author gratefully acknowledges the kind support of the Bundeskartellamt, especially Stephanie Brinster, Gero Meeßen and Konrad Ost. He would also like to thank Christoph Engel, Andy Gavil, Michael Harker, Morten Hviid, Judith Mehta and Mathias Siems for their helpful comments during the preparation of this study and on earlier drafts of this paper. Any mistakes remain the responsibility of the author. The support of the ESRC, the Centre for Competition Policy, the Max Planck Institute for Research on Collective Goods and the Faculty of Social Sciences are gratefully acknowledged.

Contact Details: Comments are gratefully received at s.peyer@uea.ac.uk 


\section{Contents}

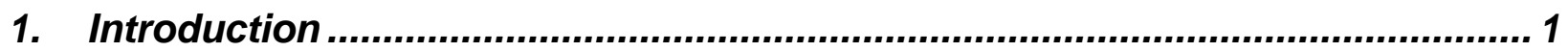

2. Private antitrust developments in Europe .................................................... 4

2.I. European private antitrust policy ............................................................... 4

2.2 Private antitrust enforcement policy in Germany ........................................ 7

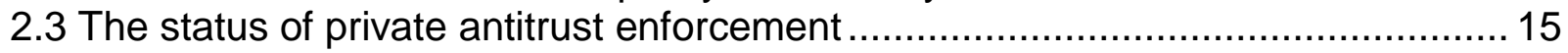

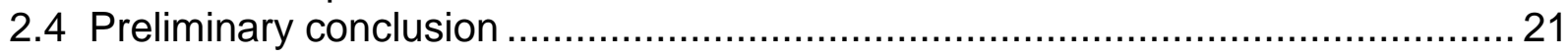

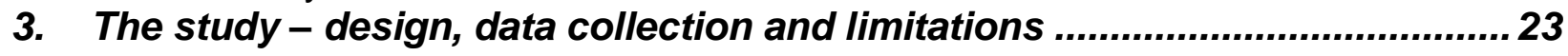

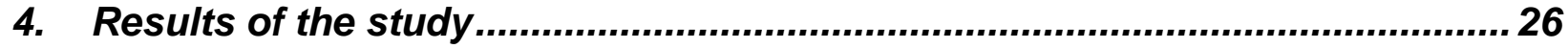

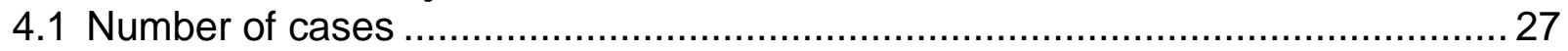

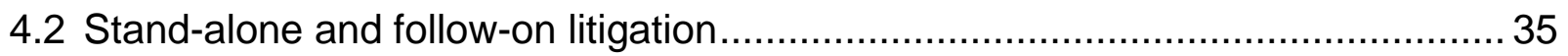

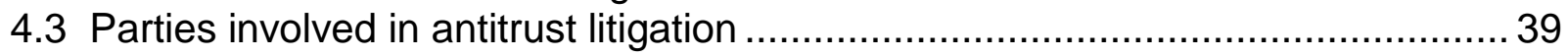

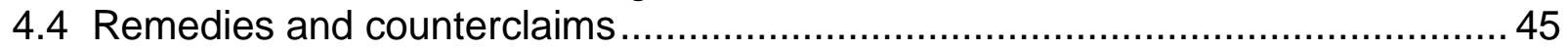

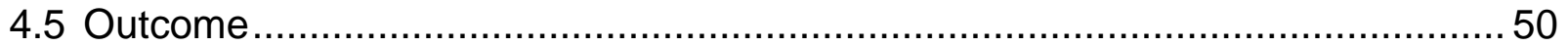

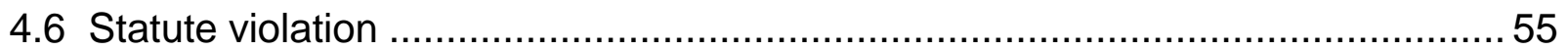

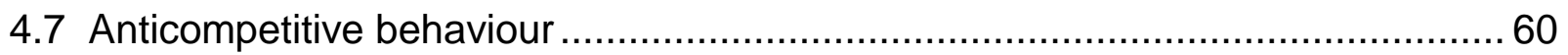

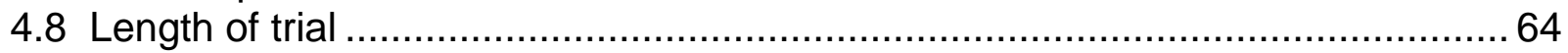

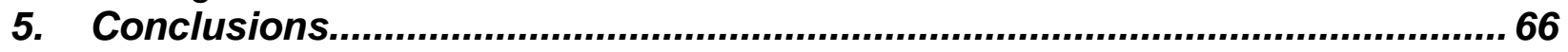

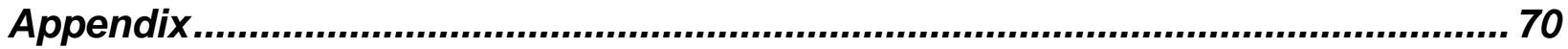




\section{Introduction}

Over the last decade, the enforcement of European competition law has seen major changes. ${ }^{1}$ Particularly the enactment of Regulation 1/2003 brought a notable shift towards the decentralised enforcement of the competition rules and the opportunity for the national courts to rule on private antitrust cases. ${ }^{2}$ While decentralised public enforcement within the European Competition Network seems to become a success story, ${ }^{3}$ the status of private enforcement of European competition law is less clear. Is it as underdeveloped as the European Commission claims? And if it is not, what do private antitrust actions in the Member States look like? And finally, are legislative measures required to foster the private rights of action? These and other questions have been subject to an extensive debate covering, for instance, issues like the goals, the appropriate role of private enforcement in combination with public enforcement and the potential features of private claims. ${ }^{4}$ The Courage ${ }^{5}$ decisions of the European Court of Justice (ECJ), and later the ruling in Manfredi, ${ }^{6}$ according to which individuals have the right to compensation, provided the background for the private antitrust discussion in Europe.

Building on the Courage case, the European Commission took the initiative to build a framework for private antitrust litigation in the EU Member States. Under its damages actions reform ('European private antitrust policy') the European Commission proposed

\footnotetext{
${ }_{1}^{1}$ The expressions competition law and antitrust law are used synonymously.

${ }^{2}$ Council Regulation (EC) No. 1/2003 of 16 December 2002 on the implementation of the rules on competition laid down in Articles 81 and 82 of the Treaty. OJ 2003 L 1/1 (2002).

${ }^{3}$ Hussein Kassim and Kathryn Wright, 'Bringing Regulatory Processes Back In: The Reform of EU Antitrust and Merger Control' [2009] 32 West European Politics 738; Firat Cengiz, 'Regulation 1/2003 Revisited' [2009] SSRN eLibrary.

${ }^{4}$ For the controversy about the role of private enforcement in Europe see, for instance, the debate between Wouter $\mathrm{P}$ Wils, 'Should Private Enforcement Be Encouraged in Europe?' (2003) 26 World Competition 472. and Clifford A Jones, 'Private Antitrust Enforcement in Europe: A Policy Analysis and Reality Check' (2004) 27 World Competition 13, or the critical appraisal of Jürgen Basedow, 'Das Kartelldeliktsrecht und der "More Economic Approach"' (2006) Europäische Zeitschrift für Wirtschaftsrecht 97. For European developments of private antitrust enforcement in general see Clifford A Jones, Private Enforcement of Antitrust Law in the EU, UK and USA (Oxford University Press, Oxford 1999); Claus-Dieter Ehlermann and Isabela Atanasiu (eds), 'Effective Private Enforcement of EC Antitrust Law' (European Competition Law Annual 6.2001, 2003); Jürgen Basedow (ed), Private Enforcement of EC Competition Law (International competition law series, Kluwer Law International, Alphen a. d. Rijn 2007); Assimakis $P$ Komninos, EC Private Antitrust Enforcement: Decentralised Application of EC Competition Law by National Courts (Hart, Oxford and Portland, Oregon 2008).

${ }^{5}$ Courage Limited v Bernard Crehan [2001] ECR I-06297.

${ }^{6}$ Manfredi v Lloyd Adriatico Assicurazioni SpA [2006] ECR I-6619.
} 
rules to be implemented in the laws of the Member States. These rules aim at eased access to damages actions for those who have suffered a loss from breaches of Articles 101 or $102 \mathrm{TFEU}^{7} .{ }^{8}$ Maybe influenced by this development, some Member States have already undertaken steps to encourage and structure civil actions against breaches of national and EU competition law. ${ }^{9}$ Germany changed its Act Against Restraints of Competition (ARC) in 2005 facilitating actions against firms breaching the competition rules. Despite those efforts already undertaken in some Member States, the European private antitrust policy will, in all likelihood, necessitate further amendments of national laws.

Although the proposed amendments have been extensively dealt with in the documents accompanying the reform, ${ }^{10}$ it seems that the underlying assumption about the nature and status of private antitrust enforcement received less attention. It is normally

\footnotetext{
${ }^{7}$ To avoid confusion I will refer to the current numbering of the EU competition rules under the Treaty of Lisbon throughout this paper.

${ }^{8}$ European Commission, Green Paper - Damages Actions for Breach of the EC Antitrust Rules (Brussels 2005) http://ec.europa.eu/comm/competition/antitrust/actionsdamages/documents.html\#greenpaper accessed 26 March 2010; European Commission, White Paper on Damages Actions for Breach of the EC Antitrust Rules (Brussels 2008) http://ec.europa.eu/competition/antitrust/actionsdamages/documents.html\#whitepaper accessed 26 March 2010.

${ }^{9}$ The UK Enterprise Act amended the Competition Act 1998 introducing rules to foster private claims. Section 47A of the Competition Act 1998 provides for monetary follow-on claims before the Competition Appeal Tribunal. Section 47B provides for consumer claims by specified bodies and section 58 and 58A declare findings of facts of the OFT and findings of an infringement by the OFT or Competition Appeal Tribunal binding in court proceedings. For further details see Barry J Rodger, 'Private Enforcement and the Enterprise Act: An Exemplary System of Awarding Damages' (2003) 24 European Competition Law Review 103; Barry J Rodger, 'The Competition Act and the Enterprise Act Reforms: Sanctions and Deterrence in UK Competition Law' in Gerhard Dannecker and Oswald Jansen (eds), Competition Law Sanctioning in the European Union: The EU-law Influence on the National Law System of Sanctions in the European Area (Kluwer Law International, The Hague, New York 2004); Lesley Farrel and Sarah Ince, 'United Kingdom: Private Enforcement' [2007] Oct Supp (The European Antitrust Review) G.C.R 226. Italy just recently introduced a class action devise. Alberto Martinazzi, 'Developments in Private Enforcement of Italian Antitrust Law: The Introduction of "Class Action" Legislation' (2010) Competition Policy International 1. In Spain, the LEY 15/2007 de Defensa de la Competencia paved the way for a private enforcement of national and EC antitrust rules. Ignacio Sancho Gargallo, 'Private Enforcement of EU and National Competition Law' [2009] 1 InDret.

${ }^{10}$ Denis Waelbroeck, Donald Slater and Gil Even-Shoshan, Study on the Conditions for the Claims of Damages in Case of Infringement of EC Competition Rules: National Report United Kingdom (Brussels 2004); European Commission, Commission Staff Working Paper: Annex to the Green Paper Damages Actions for Breach of the EC Antitrust Rules (Brussels 2005) http://ec.europa.eu/comm/competition/antitrust/actionsdamages/documents.html\#staffpaper accessed 26 March 2010; European Commission, Commission Staff Working Paper accompanying the White Paper on Damages Actions for Breach of the EC Antitrust Rules (Brussels 2008)

http://ec.europa.eu/competition/antitrust/actionsdamages/documents.html\#link1 accessed 26 March 2010; European Commission, Commission Staff Working Document - Impact Assessment. Accompanying Document to the White Paper on Damages Actions for Breach of the EC Antitrust Rules (Brussels 2008) http://ec.europa.eu/comm/competition/antitrust/actionsdamages/documents.html\#link1 accessed 26 March 2010; Andrea Renda and others, Making Antitrust Damages Actions More Effective in the EU: Welfare Impact and Potential Scenarios: Final Report. Report for the European Commission Contract DG COMP/2006/A3/012 (Brussels, Rome, Rotterdam 2008) http://ec.europa.eu/competition/antitrust/actionsdamages/documents.html accessed 26 March 2010.
} 
assumed that private antitrust enforcement in general, and private damages actions in particular, are totally underdeveloped in the Member States of the European Union. This belief originates from two - not primarily empirical - studies authorised by the European Commission. ${ }^{11}$ However, because of, or despite, these studies this main assumption lacks in-depth empirical evidence from most Member States ${ }^{12}$ and has sparked criticism. ${ }^{13}$

This paper will pursue the empirical issue for one Member State further exploring the nature and magnitude of private antitrust enforcement in Germany. I will look at cases that were concluded before German courts between 2005 and 2007. Germany is probably a typical-atypical example for private antitrust litigation in the EU. Recent years have seen some legal changes in order to facilitate claims for the breach of competition law in both Germany and other Member States like the UK, Spain and Italy. With respect to the degree to which claim-facilitating rules have been implemented, Germany might be representative for other Member States. On the other hand, Germany is one of the economically strongest states in the EU27. It has also a comparatively long history of enforcement of national antitrust rules distinguishing it from most of its European neighbours. Germany may not stand pars pro toto for all Member States but it is hoped that this research provides an insight into extent and nature of private antitrust enforcement, especially in civil law jurisdictions, and feeds the debate about measures to enhance private antitrust enforcement with more data.

Providing a brief overview about developments in European private antitrust enforcement in the next section, I will describe the current European private antitrust policy and parallel developments in Germany. As for Germany, I outline the legal framework for litigation against breaches of European and national competition law. The

\footnotetext{
${ }^{11}$ Denis Waelbroeck, Donald Slater and Gil Even-Shoshan, Study on the Conditions for the Claims of Damages in Case of Infringement of EC Competition Rules: Comparative Report (Brussels 2004); Renda and others ( $\mathrm{n}$ 11).

${ }^{12}$ The notable exceptions are Rodger's studies in the United Kingdom: Barry J Rodger, 'Competition Law Litigation in the UK Courts, A Study of All Cases to 2004' (2006) 27 European Competition Law Review 241; Barry J Rodger, 'Private Enforcement of Competition Law, the Hidden Story: Competition Litigation Settlements in the United Kingdom, 2000-2005' (2008) 29 European Competition Law Review 96; Barry J Rodger, 'Competition Law Litigation in the UK Courts: A Study of all Cases 2005-2008, Part l' (2009) 2 Global Competition Litigation Review 93.

${ }^{13}$ Ulf Böge and Ost Konrad, 'Up and Running, or Is It? Private Enforcement - The Situation in Germany and Policy Perspectives' (2006) 27 European Competition Law Review 197.
} 
section concludes with a very brief summary of already existing studies of antitrust litigation. Section $C$ describes the original data used for this study, the design of the study, the data collection process, and unfolds the limitations of this project. Part D presents the findings of my study. Part E concludes.

\section{Private antitrust developments in Europe}

In this part I outline the European and German private antitrust policy and the measures that are supposed to foster private antitrust actions. At the same time, I will look at the assumptions on which this private antitrust policy is based.

\subsection{European private antitrust policy}

Private enforcement of the competition laws in Europe gained increasing attention following the turn of the millennium. ${ }^{14}$ Especially after the ECJ's Courage ruling the debate gathered momentum. One of the reasons for the long absence of private antitrust from competition policy is probably the unique setup in Europe: while the European Commission and the European courts are very present in public competition law enforcement they have little influence on private antitrust litigation. Civil actions based on violations of competition rules are brought before the national courts of the Member States and the European courts are not competent to hear such claims in the first place. The European Court of Justice only rules on preliminary references made by national courts like, for instance, in the seminal Courage and Manfredi cases. Although the ECJ rarely rules on private cases, it did so with a wide impact on these two occasions. The dispute between Inntrepreneur Estates (formerly Courage) and $\mathrm{Mr}$ Crehan concerning a beer tie agreement led to the ECJ's Courage decision in $2001 .^{15}$ The Court stated that "[...] the practical effect of the prohibition laid down in Article 85(1)

\footnotetext{
${ }^{14}$ For an overview about the discussion before see Barry J Rodger and Angus MacCulloch, 'Wielding the Blunt Sword: Interim Relief for Breaches of EC Competition Law before the UK Courts' (1996) 17 European Competition Law Review 393; Andrew Maxwell and Stephen Kon, 'Enforcement in National Courts of the E.C. and New U.K. Competition Rules: Obstacles to Effective Enforcement' (1998) 19 European Competition Law Review 443; Jones (n 5).

${ }^{15}$ Courage Limited v Bernard Crehan (n 6). For facts underpinning the Courage litigation see Michael Waterson, Beer - The Ties that Bind (2010) http://www2.warwick.ac.uk/fac/soc/economics/research/workingpapers/2010/twerp 930.pdf accessed 17 May 2010.
} 
[Art 101(1)] would be put at risk if it were not open to any individual to claim damages for loss caused to him by a contract or by conduct liable to restrict or distort competition." ${ }^{16}$ This right of individuals to seek compensation for harm imposed on them by violations of the competition rules was confirmed again in Manfredi, a decision made upon reference from an Italian court. ${ }^{17}$ The Court held that it follows from the principle of effectiveness that national law should provide an effective (damages) remedy for any individual injured by a competition law violation.

The Courage litigation finally put private antitrust enforcement on the agenda in Europe and sparked numerous comments and contributions related to private antitrust enforcement. ${ }^{18}$ The Modernisation Regulation 1/2003 endowing the national courts with the powers to decide in all matters related to Articles 101 and 102 accelerated the process because it opened the gates for an exhaustive application of European antitrust law in the courts of the Member States. ${ }^{19}$ The European Commission then took initiative and published its Green Paper on damages actions for the breach of the EC antitrust rules. $^{20}$ The Green Paper tried to identify the main obstacles for private actions and reflected on possible measures to improve the conditions for follow-on and stand-alone damages claims. Having received numerous comments on the Green Paper and taking

\footnotetext{
${ }_{17}^{16}$ Courage Limited v Bernard Crehan (n 6) para 26.

${ }_{17}$ Manfredi v Lloyd Adriatico Assicurazioni SpA (n 7).

${ }^{18}$ Barry J Rodger, 'The Interface Between Competition Law and Private Law: Article 81, Illegality and Unjustified Enrichment' (2002) 6 Edinburgh Law Review 217; Jonathan Sinclair, 'Damages in Private Antitrust Actions in Europe' (2002) 14 Loyola Consumer Law Review 547; Assimakis P Komninos, 'New Prospects for Private Enforcement of EC Competition Law: Courage v. Crehan and the Community Right to Damages' (2002) 39 Common Market Law Review 447; Rolf Hempel, Privater Rechtsschutz im Kartellrecht: Eine rechtsvergleichende Analyse (Wirtschaftsrecht und Wirtschaftspolitik, $1^{\text {st }}$ edn Nomos-Verl.-Ges. Baden-Baden 2002); James Edelman and Okeoghene Odudu, 'Compensatory Damages for Breach of Article 81' (2002) 27 European Law Review 327; Daniel Beard and Alison Jones, 'Co-contractors, Damages and Article 81: The ECJ Finally Speaks' (2002) 23 European Competition Law Review 246; Wolfgang Wurmnest, 'Zivilrechtliche Ausgleichsansprüche von Kartellbeteiligten bei Verstößen gegen das EG-Kartellverbot' (2003) 49 RIW 896; Wils (n 5); Rodger (n 10); Ehlermann and Atanasiu (eds) (n 5); Ehlermann and Atanasiu (eds) (n 5); Jürgen Basedow, 'Private Enforcement of Article 81 EC: A German View' in Claus-Dieter Ehlermann and Isabela Atanasiu (eds), Effective Private Enforcement of EC Antitrust Law (European Competition Law Annual, Hart, Oxford 2003); Katherine Holmes, 'Public Enforcement or Private Enforcement? Enforcement of Competition Law in the EC and UK' (2004) 25 European Competition Law Review 25; Arianna Andreangeli, 'Courage $\checkmark$ Crehan and the Enforcment of Article 81 EC Before the National Courts' (2004) 25 European Competition Law Review 758; Wils, Wouter P. J. Principles of European Antitrust Enforcement (Hart Publishing, Oxford 2005); Douglas H Ginsburg, 'Comparing Antitrust Enforcement in the United States and Europe' (2005) 1 Journal of Competition Law and Economics 427; Maja Brkan, 'Procedural Aspects of Private Enforcement of EC Antitrust Law: Heading Toward New Reforms?' (2005) 28 World Competition 479.

${ }^{19}$ Council Regulation (EC) No 1/2003 of 16 December 2002 on the implementation of the rules on competition laid down in Articles 81 and 82 of the Treaty OJ L 1, 04.01.2003, 1-25.

${ }^{20}$ European Commission, Green Paper (n 9).
} 
into account the Manfredi case, the Commission released its White Paper on EC damages actions in 2008. ${ }^{21}$ In the White Paper, the Commission recommended a set of rules that should be introduced into the laws of the Member States to foster private damages actions for the infringement of Art 101 and $102 .^{22}$ These proposals are claimed to be "[...] balanced measures that are rooted in European legal culture and traditions." 23 To implement these measures it would require significant changes in the substantial and procedural laws of most Member States. Subsequently, the Commission drafted a directive which basically contained the proposals laid out in the White Paper. This draft directive was put on hold because some Member States resisted the Commission's proposals. It remains to be seen whether the draft Directive can be adopted in its current form and despite the resistance of some Member States and the European Parliament.

The debate about the private rights to action is based on the assumption that private enforcement is completely underdeveloped in Europe. It is taken for granted that private actions against anticompetitive behaviour are of little or no significance in the overall enforcement scheme in European countries. To illustrate their arguments commentators often refer to the US Georgetown Study that stated that 90 per cent of US antitrust enforcement between 1973 and 1983 were private. ${ }^{24}$ Despite this slightly skewed comparison, the assumption of underdevelopment in Europe is not entirely unsubstantiated. A considerable amount of resources has been spent to learn more

\footnotetext{
${ }^{21}$ European Commission, White Paper (n 9).

${ }^{22}$ For a discussion of the various White Paper proposals see Renato Nazzini and Ali Nikpay, 'Private Actions in EC Competition Law' (2008) 4 Competition Policy International 107; Christian Kersting, 'Perspectives for Private Enforcement in European Antitrust Law' (2008) http://ssrn.com/abstract=1161254 accessed 16 September 2008; Christopher J Cook, 'Private Enforcement of Competition Law in Member State Courts: Experience to Date and the Path Ahead' (2008) 4 Competition Policy International 3; Derek Ridyard, 'Indirect Effects and Unintended consequences: a Comment on the Commission's white Paper on Private Actions' (2009) 2 Global Competition Litigation Review 115; Emmanuela Truli, 'White Paper on Damages Actions for Breach of the EC Antitrust Rules: The Binding Effect of Decisions Adopted by National Competition Authorities' (2009) 5 European Competition Journal 795; Jeroen S Kortmann and Christof R A Swaak, 'The EC White Paper on Antirust Damages Actions: Why the Member States are (right to be) less than enthusiastic' (2009) 30 European Competition Law Review 340; Mihail Danov, 'Awarding Exemplary (or Punitive) Antitrust Damages in EC Competition Cases With an International Element - the Rome II Regulation and the Commission's White Paper on Damages' (2009) 29 European Competition Law Review 430; Jindrich Kloub, 'White Paper on Damages Actions for Breach of the EC Antitrust Rules: Plea for a More Holistic Approach' (2009) 5 European Competition Journal 515.

${ }^{23}$ European Commission, White Paper (n 9) 3 (emphasis in original).

${ }^{24}$ Lawrence J White (ed), Private Antitrust Litigation: New Evidence, New Learning (MIT Press, Cambridge Mass. 1988) 3. Since the publication of the Georgetown data the number of private antitrust cases has dropped considerably.
} 
about private litigation. Preparing its Green Paper, the European Commission authorised a study on the conditions for damages claims in case of infringement of the EC Competition Rules (Ashurst Study). ${ }^{25}$ The Welfare Impact Report, underpinning the White Paper, prepared by an international team of researchers, also presented data on litigation in the courts of the Member States. ${ }^{26}$ Both studies, however, focused on damages actions and neglected other types of antitrust remedies. Although the focus and methods used to compile information about case are debatable, there is some reason behind the Commission's claim. Based on evidence from these reports the European Commission came to the conclusion that there is a "[...] lack of an effective legal framework for private actions seeking compensation for the damages caused $[\ldots]{ }^{27}$

The European private antitrust policy has certainly raised the awareness of antitrust litigation in the Member States. However, the precise proposals are contentious. Collective action devises, discovery procedure or other measures intended to improve private enforcement are alien to many jurisdictions and, consequently, did not receive a very warm welcome. ${ }^{28}$ Unfortunately, most commentators do not deal with the assumptions on which the proposals are based. Furthermore, there has been little resistance against the presumption that the diversified rules in the Member States actually cause the (assumed) lack of private cases. ${ }^{29}$

\subsection{Private antitrust enforcement policy in Germany}

In this section, I will describe the current legal framework highlighting recent policy changes and amendments of the Act Against Restraints of Competition (ARC) related to

\footnotetext{
${ }^{25}$ Waelbroeck, Slater and Even-Shoshan (n 12).

${ }^{26}$ Renda and others ( $n$ 11). Both studies the Welfare Impact Report and the Ashurst Study will be explained in more detail below.

${ }^{27}$ European Commission, Commission Staff Working Document (n 11).

${ }^{28}$ Ulf Böge, 'Public and Private Enforcement: Harmony or Discord' (2006) 5 Competition Law Journal 114; Jon Lawrence, 'Seeking the Perfect Balance: Some Reflections on the Commission's Green Paper on Damages Actions for Breach of the EC Antitrust Rules' in Claus-Dieter Ehlermann and Isabela Atanasiu (eds), Enforcement of Prohibition of Cartels (European Competition Law Annual, Hart, Oxford 2007); Thomas Eilmansberger, 'The Green Paper on Damages Actions for Breach of the EC Antitrust Rules and Beyond: Reflections on the Utility and Feasibility of Stimulating Private Enforcement Through Legislative Action' (2007) 44 Common Market Law Review 431.

29 This point was made by Kortmann. Kortmann and Swaak (n 23) 350.
} 
litigation for breaches of European or German competition law. ${ }^{30}$ I will not, however, address contentious issues surrounding the substantive provisions of the ARC and the proposals being made to solve those problems.

Similar to the development of private antitrust actions on the European level, private enforcement of national competition law did not gain much attention until the late $20^{\text {th }}$ century. ${ }^{31}$ It was only after the millennium that an increasing number of academics and practitioners started exploring this topic in-depth, for example, by comparing private enforcement regimes across jurisdictions or looking into the procedural or substantive details of private antitrust. ${ }^{32}$ When the ARC came into force in 1958, private actions

\footnotetext{
${ }^{30}$ For a brief overview of the current setup in Germany see Wolfgang Wurmnest, 'A New Area for Private Antitrust Litigation in Germany? A Critical Appraisal of the Modernized Law Against Restraints of Competition' (2005) 6 German Law Journal 1173; Thomas Lübbig and Miriam Le Bell, 'Die Reform des Zivilprozesses in Kartellsachen' (2006) Wettbewerb in Recht und Praxis 1209.

${ }^{31}$ Hans Goll, '§ 22 GWB ein Schutzgesetz?' (1976) WuW 291; Hans Goll, 'Verbraucherschutz im Kartellrecht' (1976) GRUR 486; Hans-Martin Müller-Laube, Der private Rechtsschutz gegen unzulässige Beschränkungen des Wettbewerbs und mißbräuchliche Ausübung von Marktmacht im deutschen Kartellrecht (Schriften zum Wirtschaftsrecht, Duncker \& Humblot, Berlin 1980); Ludwig Linder, Privatklage und Schadensersatz im Kartellrecht: Eine vergleichende Untersuchung zum deutschen und amerikanischen Recht. Univ. Diss.--Tübingen, 1979. (Wirtschaftsrecht und Wirtschaftspolitik, Nomos-Verl.-Ges. Baden-Baden 1980); Karsten Schmidt, 'Offenhaltung der Märkte durch private Klagen bei Kartellsachverhalten? - Ein Beitrag zur Schutzgesetzdiskussion um § 35 GWB' in Clemens-August Andreae (ed), Wettbewerb als Herausforderung und Chance: Festschrift für Werner Benisch (Heymann, Köln 1989); Rüdiger Volhard, 'Schadensersatz bei Preisabsprachen in der neueren Rechtsprechung' in Gisela Wild, Ine-Marie Schulte-Franzheim and Monika Lorenz-Wolf (eds), Festschrift für Alfred-Carl Gaedertz zum 70. Geburtstag (Beck, München 1992); Ernst Steindorff, EG-Vertrag und Privatrecht (Schriftenreihe Europal0308isches Recht, Politik und Wirtschaft, Nomos, Baden-Baden 1996); Rainer Traugott, 'Anspruch auf Belieferung aus Art 85 Abs 1 EGV in Verbindung mit § 823 Abs 2 BGB und § 249 Satz 1 BGB?' (1997) WuW 486; Stephanie Haslinger, 'Zum Belieferungsanspruch aufgrund Art 85 EGV iVm § 823 II, $249 f f$ BGB' (1998) WuW 456. ${ }_{32}$ Hempel (n 19); Rolf Hempel, 'Privater Rechtsschutz im deutschen Kartellrecht nach der 7. GWB Novelle' (2004) 54 WuW 362; Friedrich W Bulst, 'Private Kartellrechtsdurchsetzung durch die Marktgegenseite - deutsche Gerichte auf Kollisionskurs zum EuGH' (2004) NJW 2201; Monopolkommission, Das allgemeine Wettbewerbsrecht in der Siebten GWB-Novelle: Sondergutachten der Monopolkommission gemäß § 44 Abs. 1 Satz 4 GWB (Bonn 2004) http://www.monopolkommission.de/sg_41/text_s41.pdf accessed 30 May 2008; Monopolkommission (n 33); Rolf Hempel, 'Private Follow-on Klagen im Kartellrecht' (2005) 55 WuW 137; Wurmnest (n 31); Frank Breitkreutz, Das Kartellverbot als Schutzgesetz: Ein Beitrag zum Drittschutz im Kartellrecht. Univ. Diss.--Rostock, 2004. (Rostocker Schriften zum Wirtschaftsrecht, Kovac, Hamburg 2005); Bundeskartellamt, Private Kartellrechtsdurchsetzung - Stand, Probleme, Perspektiven: Diskussionspapier für die Sitzung des Arbeitskreises Kartellrecht am 26. September 2005 (Bonn 2005) http://www.bundeskartellamt.de/wDeutsch/download/pdf/Diskussionsbeitraege/05 Proftag.pdf accessed 26 March 2010; Georg M Berrisch and Markus Burianski, 'Kartellrechtliche Schadensersatzansprüche nach der 7. GWB-Novelle' (2005) WuW 878; Wulf-Henning Roth, 'Das Kartelldeliktsrecht in der 7. GWB-Novelle' in Theodor Baums and others (eds), Festschrift für Ulrich Huber: Zum siebzigsten Geburtstag (Mohr Siebeck, Tübingen 2006); Friedrich W Bulst, Schadensersatzansprüche der Marktgegenseite im Kartellrecht: Zur Schadensabwälzung nach deutschem, europäischem und US-amerikanischem Recht (Europäisches Wirtschaftsrecht, ${ }^{\text {st }}$ edn Nomos, BadenBaden 2006); Jürgen Keßler, 'Private Enforcement - Zur deliktsrechtlichen Aktualisierung des deutschen und europäischen Kartellrechts im Lichte des Verbraucherschutzes' (2006) Wettbewerb in Recht und Praxis 1061; Christian Schwedler, Die private Durchsetzung des Kartellrechts in den USA, Europa und Deutschland (Schriftenreihe des Studiengangs Wirtschafts- und Umweltrecht der FH- Trier, Umwelt-Campus Birkenfeld, Bülow, Rothenburg 2006); Michael Meyer, 'Die Bindung der Zivilgerichte an Entscheidungen im Kartellverwaltungsrechtsweg - der neu § 33 IV GWB auf dem Prüfstand' (2006) WuW 27; Günter Hirsch, 'Private Enforcement of EC Competition Law - Developments in Germany' (2006) 5 Competition Law Journal 108; Böge and Ost Konrad (n 14); Böge (n 29); Christian Göertz, Private Durchsetzung von Kartellrecht in Deutschland, Österreich und der Schweiz
} 
were assumed to be part of the overall enforcement scheme. In its original form, the $A R C$ already provided an obligation of the courts to inform the competition authority about antitrust cases that were brought before them. ${ }^{33}$ It was thought that this rule would enable the Federal Cartel Office (FCO) to realise the public interest in civil litigation. ${ }^{34}$ However, the dominant enforcement mode was deemed to be public. Private enforcement moved further into the public focus with litigation being brought after the Vitamin decision of the European Commission, ${ }^{35}$ the Courage ruling, ${ }^{36}$ and the Modernisation Regulation 1/2003. With the modernisation of the application of European competition law it became necessary to align German competition law with Article 101. Delayed by one year, the $7^{\text {th }}$ amendment of the ARC, put into effect on 1 July 2005, translated European standards into national law, notably changing and introducing section 33 and $89 a$ of the ARC respectively. ${ }^{37}$ The reform also contained rules which were hoped to clarify and improve the conditions for private antitrust enforcement.

(Rechtswissenschaftliche Forschungsberichte, Mensch \& Buch Verlag, Berlin 2007); André Görner, Die Anspruchsberechtigung der Marktbeteiligung nach § 33 GWB. Univ. Diss.-2007--Mainz, 2006. (FIW-Schriftenreihe, Heymann, Köln 2007); Wernhard Möschel, 'Behördliche oder privatrechtliche Durchsetzung des Kartellrechts?' (2007) WuW 483; Wernhard Möschel, 'Should Private Enforcement of Competition Law Be Strengthened?' in Dieter Schmidtchen, Max Albert and Stefan Voigt (eds), The More Economic Approach to European Competition Law (Conferences on new political economy, Mohr Siebeck, Tübingen 2007); Florian Endter, Schadensersatz nach Kartellverstoß: Eine rechtsvergleichende Untersuchung der Anspruchsgrundlagen im europäischen, deutschen und englischen Recht (Münchner Schriften zum Europäischen und Internationalen Kartellrecht, Stämpfli, Bern 2007); George Cumming, Brad Spitz and Ruth Janal, Civil Procedure Used for Enforcement of EC Competition Law by the English, French and German Civil Courts (International competition law series, Kluwer Law International, Alphen aan den Rijn 2007); Lysann Beu, Private Enforcement: Die Stellung der Verbraucher bei der Durchsetzung von Schadensersatz- und Unterlassungsansprüchen im deutschen Kartellrecht (1 $1^{\text {st }}$ edn VDM Verlag Dr. Müller, Saarbrücken 2007); Christina Kaufmann, Rechtsschutz im deutschen und europäischen Kartellrecht: Konzeption einer effektiven Schadensersatzklage (VDM Müller, Saarbrücken 2007); Moritz Votteler, Der Schadensersatzanspruch im EG-Kartellrecht: Existenz und Ausgestaltung. Univ. Diss.--Passau, 2008. (Studienreihe Wirtschaftsrechtliche Forschungsergebnisse, Kovac, Hamburg 2008); Hans P Logemann, Der kartellrechtliche Schadensersatz: Die zivilrechtliche Haftung bei Verstößen gegen das deutsche und europäische Kartellrecht nach Ergehen der VO (EG) Nr. 1/2003 und der 7. GWB-Novelle. Univ. Diss.--Bonn, 2008. (Beiträge zum europäischen Wirtschaftsrecht, Duncker \& Humblot, Berlin 2009); Alexander Kruß, Kartellschaden und Verbraucherschutz: Rechtliche und faktische Rechtsdurchsetzungshürden für die Kompensation kartellbedingter Streuschäden unter Berücksichtigung gemeinschaftsrechtlicher Vorgaben. Univ. Diss.--Trier, 2009. (Studienreihe Wirtschaftsrechtliche Forschungsergebnisse, Kovac, Hamburg 2010); Christian Alexander, Schadensersatz und Abschöpfung im Lauterkeits- und Kartellrecht (Mohr Siebeck, Tübingen 2010).

${ }^{33}$ Gerhard Hitzler, 'Die Beteiligung der Kartellbehörden an Kartellstreitigkeiten nach § 90 GWB' (1982) WuW 509.

${ }^{34}$ Amtliche Begründung zu dem Entwurf eines Gesetzes gegen Wettbewerbsbeschränkungen, BT-Drucks. II-1158 C $\$ 65$ Ziff. 1.

35 Vitamins (2001) 4 OJ.

${ }^{36}$ Courage Limited v Bernard Crehan (n 6).

37 Siebtes Gesetz zur Änderung des Gesetzes gegen WettbewerbsbeschränkungenBundesgesetzblatt (BGBI.) 2005, Part I, 1954-1969. 
Section 1 ARC prohibits horizontal and vertical agreements similarly to Article 101. Section 2 ARC corresponds with Article 101(3). Some agreements of medium-sized firms are excluded from the prohibition in section 1 if they meet the conditions laid out in section 3 ARC. Prior to the $7^{\text {th }}$ amendment of the ARC, vertical agreements were not included in the prohibition of section 1 ARC. Until then only vertical agreements binding prices and terms were per se prohibited. ${ }^{38}$ Before 2005 exclusive dealing agreements and other vertical distribution agreements were only controlled in respect of abuse and there was little room for private enforcement. ${ }^{39}$ With respect to unilateral conduct German law still differs from the European law as the $7^{\text {th }}$ amendment of the ARC made use of Article 3 of the Modernisation Regulation. This provision granted the Member States the right to maintain stricter rules for the abuse of market power. The control of unilateral conduct in the ARC is based on three pillars: section 19 ARC prohibits the abuse of dominance, section 20 ARC restricts the discrimination and hindrance by dominant firms and undertakings with relative market strength, and section 21 ARC bans other undue business conduct such as boycotts. While section 19 ARC prohibits the abuse of dominance similarly to Article 102, section 20 disqualifies the abuse of relative market strength and incorporates a significant difference to European law. According to section 20(1) ARC, dominant undertakings or associations of undertakings shall not directly or indirectly discriminate or hinder other undertakings without justification. Paragraph 2 of this provision extends the prohibition including nondominant undertakings (or associations of undertakings) if small or medium-sized firms depend on them as suppliers or purchasers (economic dependency). A small or medium-sized undertaking is dependent if it cannot reasonably switch to other suppliers or purchasers, or switching is not sufficiently possible. The concept of relative market power does not only apply to vertical relationships but is also extended to undertakings that have superior market power in relation to their small and medium-sized competitors. According to paragraph 4 of section 20, undertakings with superior market power compared with small and medium-sized competitors shall not hinder or obstruct their rivals in an unjust way, for example, by pricing below cost. Not only the (missing)

\footnotetext{
${ }^{38}$ Section 14 ARC old.

${ }^{39}$ Möschel (n 33) 103.
} 
prerequisite of dominance distinguishes section 19 and 20 ARC. The wording of section 19 and 20 ARC differs as well: the former refers to an abuse of dominance while the latter mentions discrimination and hindrance. However, the meaning remains roughly the same. It is claimed that, in practice, section 20 ARC only becomes relevant if the dominance criterion required in section 19 ARC is not met. ${ }^{40}$ Otherwise, sections 19(1), 20(1) and (4) ARC overlap with regard to the type of conduct concerned. ${ }^{41}$ Section 20(6) addresses the conduct of professional and business associations which shall not refuse to accept applications for membership if the refusal would amount to an unjustified discrimination and lead to an unfair disadvantage of the undertaking concerned. Finally, section 21 ARC disqualifies other anticompetitive conduct and bans boycotts; that are requests made to third parties to refuse to deal or supply another firm. It also bans firms under scrutiny from harming another undertaking because the latter complained to the competition authority.

Prior to the $7^{\text {th }}$ amendment of the ARC, private enforcement of the competition rules was based on both section $33 \mathrm{ARC}^{42}$ and section 823(2) of the German Civil Code. If plaintiffs alleged a breach of European law and requested damages, the claim had to be based on section 823(2) Civil Code (for the breach of a statute) in conjunction with Articles 101 and 102. For a violation of German competition law, plaintiffs could refer to section 33 ARC asking for injunctions or damages. Under both provisions plaintiffs had standing if they fell within the scope of protection of either Articles 101 and 102 or German competition law. The courts interpreted the scope of protection requirement narrowly and granted standing only if the violation was specifically directed at the plaintiff. ${ }^{43}$ This led to a number of judgements, especially follow-on damages actions in the aftermath of the European Commission's Vitamin decision, in which purchasers

\footnotetext{
${ }^{40}$ Kurt Markert, '20' in Ulrich Immenga and Ernst-Joachim Mestmäcker (eds), GWB: Kommentar zum Deutschen Kartellrecht (Wettbewerbsrecht / Immenga Mestmäcker, $4^{\text {th }}$ edn Beck, München 2007) para 1.

41 ibid. para 239.

42 Section 33 ARC of the ARC 1999 (annulled) (translation by the author): Whoever violates a provision of this Act or a decision of the competition authority is, if the provision or decision aims at the protection of an individual, obliged to cease and desist and, if he acts intentionally or negligently, he is also obliged to compensate the damage the occurred due to the violation. The request to cease and desist can also be brought forward by associations with legal capacity that promote business interest.

${ }^{43}$ BGHZ 86, 324 Familienzeitschrift.
} 
were denied standing and, thus, compensation for overcharges. ${ }^{44}$ With the modernisation of German antitrust law, all private damages actions are now based on section 33(3) ARC granting a right to compensation when European or German competition law were violated. ${ }^{45}$ At the same time, the legislator abolished the protective law requirement. The new standing test limits the number of plaintiffs to "affected parties" for both injunctions and removal requests in accordance with section 33(1) ARC. The "affected parties" restriction also applies to damages remedies provided for in section 33(3) ARC. Affected parties can be both competitors and other market participants depending on the type of infringement. It is contentious whether or not indirect purchasers have standing under the new test. ${ }^{46}$

\footnotetext{
${ }^{44}$ Landgericht Mainz, NJW-RR 2004, 478 Vitaminkartell; Oberlandesgericht Karlsruhe NJW 2004, 2243 Vitaminkartell; Landgericht Mannheim GRUR 2004, 182 Vitaminkartell.

${ }^{45}$ Section 33 ARC after the $7^{\text {th }}$ amendment of the ARC (translation by the German Federal Cartel Office):
} Claims for Injunctions, Liability for Damages

(1) Whoever violates a provision of this Act, Articles 81 or 82 of the EC Treaty or a decision taken by the cartel authority shall be obliged to the person affected to remediate and, in case of danger of recurrence, to refrain from his conduct. A claim for injunction already exists if an infringement is foreseeable. Affected persons are competitors or other market participants impaired by the infringement.

(2) The claims pursuant to paragraph 1 may also be asserted by associations with legal capacity for the promotion of commercial or independent professional interests, provided they have a significant number of member undertakings selling goods or services of a similar or related type on the same market, provided they are able, in particular with regard to their human, material and financial resources, to actually exercise their statutory functions of pursuing commercial or independent professional interests, and provided the infringement affects the interests of their members.

(3) Whoever intentionally or negligently commits an infringement pursuant to paragraph 1 shall be liable for the damages arising therefrom. If a good or service is purchased at an excessive price, a damage shall not be excluded on account of the resale of the good or service. The assessment of the size of the damage pursuant to $\S 287$ of the Code of Civil Procedure [Zivilprozessordnung] may take into account, in particular, the proportion of the profit which the undertaking has derived from the infringement. From the occurrence of the damage, the undertaking shall pay interest on its obligations to pay money pursuant to sentence $1 . \S \S 288$ and 289 sentence 1 of the Civil Code shall apply mutatis mutandis.

(4) Where damages are claimed for an infringement of a provision of this Act or of Article 81 or 82 of the EC Treaty, the court shall be bound by a finding that an infringement has occurred, to the extent such a finding was made in a final decision by the cartel authority, the Commission of the European Community, or the competition authority - or court acting as such - in another Member State of the European Community. The same applies to such findings in final judgements resulting from appeals against decisions pursuant to sentence 1. Pursuant to Article 16(1), sentence 4 of Regulation (EC) No. 1/2003 this obligation applies without prejudice to the rights and obligations under Article 234 of the EC Treaty.

(5) The limitation period of a claim for damages pursuant to paragraph 3 shall be suspended if proceedings are initiated by the cartel authority for infringement within the meaning of paragraph 1, or by the Commission of the European Community or the competition authority of another Member State of the European Community for infringement of Article 81 or 82 of the EC Treaty. $\S 204(2)$ of the Civil Code shall apply mutatis mutandis.

${ }^{46}$ Eckard Rehbinder, $§ 33$ para 14 in Ulrich Loewenheim, Karl M Meessen and Alexander Riesenkampff (eds), Kartellrecht: Kommentar (Beck, München 2009); Volker Emmerich, § 33 para 29 in Ulrich Immenga and ErnstJoachim Mestmäcker (eds), GWB: Kommentar zum Deutschen Kartellrecht (Wettbewerbsrecht / Immenga Mestmäcker, $4^{\text {th }}$ edn Beck, München 2007). 
Under general civil law rule the damages comprise of the suffered loss including foregone profits. Difficulties of damages calculations are eased under section 287 of the Civil Procedure Code. It provides for an estimation of the damages if the exact calculation is too difficult or the costs are disproportionate compared to the claimed losses. The passing-on defence is not totally excluded in Germany although it appears that it is rather unlikely to succeed in court. In principle, indirect purchasers who seek damages are not barred from legal actions against the violator. Section 33(3) does not exclude a claim for damages just because the affected good has been sold by the plaintiff. The meaning of this sentence is not entirely clear but indicates that the defendant cannot refer to the passing-on defence in case the overcharged product was sold. $^{47}$

As for injunctions, section 33(1) of the ARC states that if a provision of the ARC is infringed and the violation found to be illegal, the infringer has to remediate the affected person. If a risk of a recurrent infringements exists, which is normally presumed, an injunction will be granted requiring the defendant to undertake or to refrain from undertaking certain actions. According to sections $935 \mathrm{f}$ of the Civil Procedure Rules, plaintiffs can also ask for an injunction by way of interim relief. Interim relief is a preliminary and speedy remedy that, in theory, precludes a decision on the merits. For instance, the continuation of a delivery can temporarily be enforced by way of interim relief. ${ }^{48}$ The $7^{\text {th }}$ amendment did not change the right of parties to infer the nullity of an agreement that violates competition law. A contract which infringes Article 101 is void according to Article 101(2). Other breaches of European or national competition law may also lead to nullity if the claimant refers to section 134 of the German Civil Code. Section 134 states that a legal transaction infringing a statutory prohibition is void unless the violated statute leads to a different conclusion. Pleading the voidness of a contract, plaintiffs can make an unjust enrichment claim in order to reverse the

\footnotetext{
47 Joachim Bornkamm, § 33 in Christian Bahr, Eugen Langen and Hermann-Josef Bunte (eds), Deutsches Kartellrecht (Kommentar zum deutschen und europäischen Kartellrecht, 10. Aufl. / Luchterhand, München 2006); Lübbig and Le Bell (n 31); Christian Kersting, 'Perspektiven der privaten Rechtsdurchsetzung im Kartellrecht' (2008) Zeitschrift für Wettbewerbsrecht 252.

${ }^{48}$ Ingo Drescher, § 935 para 2 in Thomas Rauscher, Peter Wax and Joachim Wenzel (eds), Münchener Kommentar zur Zivilprozessordnung: Mit Gerichtsverfassungsgesetz und Nebengesetzen (3rd edn Beck, München 2007).
} 
(monetary) transfer that was based on the void contract. Unjust enrichment claims are brought in accordance with section 812 of the German Civil Code. If a person obtains something as the result of the performance of another person without legal grounds, the payment or value of the performance has to be returned. Usually, a contract between the plaintiff and the defendant provides the legal ground for a financial transfer. The party asking for repayment in a competition law context inherently postulates that the legal ground for the transaction is null and void due to an antitrust violation.

Class actions in which a representative requests a remedy on behalf of an anonymous group of individuals do not exist in Germany. Victims of anticompetitive conduct can consolidate their actions if the same subject matter is concerned (joinder of parties). ${ }^{49}$ Professional organisations can file an action on behalf of the group(s) they represent although the remedies are limited to injunctions (section 33(1)(2)) and disgorgement (section 34a). ${ }^{50}$ As for the latter claim, profits that have been skimmed off by professional organisation must be passed-on to the federal budget less the enforcement costs incurred. It is understandable that disgorgement claims have not been a success story as they do not provide sufficient incentives to bear the risk of litigation. The ARC does not know consumer class actions or representative actions brought by consumer organisations. The Belgian company Cartel Damages Claims ('CDC') developed of new model of amassing individual claims whereby victims of cartels cede their rights to CDC which then brings an action for damages based on the accumulated claims. ${ }^{51}$ With the first case against members of the German cement cartel still pending, the courts have approved the admissibility of this action. ${ }^{52}$

Generally, private actions must be filed before the appropriate regional court (leapfrogging the district court level), the second tier in the hierarchy of German

\footnotetext{
${ }^{49}$ Section 59 Civil Procedure Code.

${ }^{50}$ For a general overview see Jürgen Keßler, Schadensersatz und Verbandsklagerechte im Deutschen und Europäischen Kartellrecht: Gutachten im Auftrag des Verbraucherzentrale Bundesverbandes e.V (Schriftenreihe des Verbraucherzentrale-Bundesverbandes zur Verbraucherpolitik, BWV Berliner Wiss.-Verl. Berlin 2009).

${ }^{51} \mathrm{http}: / /$ www.carteldamageclaims.com/ (last accessed 22 March 2010)

52 Oberlandesgericht Düsseldorf of 14 May 2008, VI-U (Kart) 14/07 Zementkartell. For comments see Frank A Immenga, 'Für Kartellsünder bricht ein neues Zeitalter an: Nun soll es richtig wehtun!' (2007) 62 BB 1; Georg Weidenbach, 'Zementkartell: Das LG Düsseldorf als Vorreiter der Zulassung von class actions im Kartellrecht?' (2007) 62 Betriebs-Berater (BB) 847.
} 
courts. ${ }^{53}$ Appeals are made before the higher regional courts and appeals on questions of law go to the Federal Court of Justice, the highest ordinary court. Because the law provides special jurisdiction, parties cannot diverge and agree to negotiate their dispute in other ordinary courts. The modernisation of the European and German antitrust law also brought some procedural changes. New rules on evidence, prejudgement interests, limitation periods and court fees favour antitrust plaintiffs. Section 33(4) ARC introduced a binding effect of final decisions of the European Commission, German and other European competition authorities in order to facilitate follow-on actions. ${ }^{54}$ Under section 33(4) ARC plaintiffs can recover the interest from the time the damage occurred. According to paragraph 5 of section 33 ARC limitation periods stop running if public proceedings are initiated. The new section 89a ARC allows the court to adjust the value of the antitrust dispute on the request of one of the parties. Thus, the court fee may be accustomed to the party's economic situation. The German system does not know extensive discovery but applies flexible rules for the burden of proof. For instance, the burden of proof for an abuse of market power can be reversed under section 20(5) ARC if it appears on the basis of specific facts or general experience that market power was abused. If the burden of proof is reversed, it is the defendant who has to show that he did not engage in an illegal activity. However, section 20(5) only applies to cases in which undertakings with superior market power in relation to their competitors engage in an abuse. But the courts have also used common civil procedure to reverse the burden of proof. ${ }^{55}$ Under certain conditions and if the facts or circumstances to be proven are in the domain of the defendant, the court may decide that the defendant has to substantially disprove the plaintiff's claim. ${ }^{56}$

\subsection{The status of private antitrust enforcement}

In this section, I will briefly outline the major empirical studies on private antitrust enforcement in Europe in order to show what is known about private antitrust. Although the legal framework and the legal issues have been subject to detailed scrutiny and

\footnotetext{
${ }^{53}$ Section 87(1) ARC.

${ }^{54}$ For an extensive analysis see Truli (n 23).

${ }^{55}$ Landgericht Mannheim of 08 May 2009, 22 O 71/06 Netznutzungsentgelte.

${ }^{56}$ Lübbig and Le Bell (n 31).
} 
extensive debate we know very little about the existence and shape of private actions in Europe. On both the European and German level various claims have been made about the extent and nature of actions for the breach of EU and national competition law. Since most of our knowledge about private actions stems from research that has been undertaken in the United States, I will glance over the Atlantic. ${ }^{57}$ The famous US Georgetown Project, but also more recent work, have considerably advanced the knowledge about private antitrust litigation. However, one should bear in mind that the US framework is very special ${ }^{58}$ and not all of the insights can be directly transferred to European jurisdictions. Nevertheless, it provides a useful starting point for the analysis of antitrust litigation. I will also look at data from the UK and two studies covering a number of Member States.

Lin, Raj, Sandfort and Slottje provide for an overview of private and government cases in the United States from as early as 1942 until 1995. While there were less than a 100 public cases per year in the early days of US antitrust, private litigation exceeded the 100 mark in 1949 and surmounted the figure of 1,000 in $1971 .{ }^{59}$ The number of private proceedings seems to have fallen again towards the end of the observation period. In a paper published in 1970, Richard A. Posner presented his results of an investigation of civil and public enforcement of the Sherman Act from 1890 until $1960{ }^{60}$ His paper looked at the number of cases filed, the length of proceedings, the record of success of antitrust claimants, the use of various civil and criminal remedies, the pattern of violations alleged, the industries involved, the possible explanative role of politics, and measure by which antitrust statistics could be improved. His work shows that private antitrust enforcement really started in the 1940s. The success rate of private cases litigated especially before the Supreme Court is relatively high hardly falling below 50

\footnotetext{
57 There also interesting studies assessing the situation in Australia and New Zealand. Maureen Brunt, 'The Role of Private Actions in Australian Restrictive Practices Enforcement' (1990) 17 Melbourne University Law Review 582; Roberts and R Jack, International Comparative Analysis of Private Rights of Access: A Study Commissioned by Industry Canada Competition Bureau (2002) http://strategis.ic.gc.ca/pics/ct/roberts-e.pdf accessed $18 \mathrm{March} 2010$. ${ }^{58}$ Paul D Carrington, 'Moth to the Light: The Dubious Attractions of American Law' in Ulrich Hübner and Werner $F$ Ebke (eds), Festschrift für Bernhard Grossfeld zum 65. Geburtstag (Verlag Recht und Wirtschaft, Heidelberg 1999) 129.

${ }^{59}$ Ping Lin and others, 'The US Antitrust System and Recent Trends in Antitrust Enforcement' [2000] 14 Journal of Economic Surveys 255, 261.

${ }^{60}$ Richard A Posner, 'A Statistical Study of Antitrust Enforcement' (1970) 13 Journal of Law \& Economics 365.
} 
per cent for the various time periods in his study. Allegations of price fixing, price discrimination and boycotts are often the basis of private litigation.

The ground-breaking Georgetown Project still provides one of the major sources of knowledge about private antitrust enforcement although the study was conducted in the heyday of US private antitrust. Since then the courts have made it more difficult to bring private actions. The authors of the Project analysed almost 2,000 law suits from five federal districts which were brought between 1973 and 1983 and provided the basis for a number of influential papers. ${ }^{61}$ The study focused, among others, on the business relationship of plaintiffs and defendants, the outcome of the cases, the length of trial, the alleged statutory violations, remedies, costs, and industries. Assessing the Georgetown data, Elzinga and Wood pointed out that the typical antitrust case needs more resources than a civil law procedure. ${ }^{62}$ They also argued that private enforcement contributes less to economic efficiency and that public enforcement might be superior in that respect. Perloff and Rubinfeld developed a model of settlements and stressed the influence of the damages multiplier on the likelihood of settlements. ${ }^{63}$ Kauper and Snyder found that no more than 25 per cent of the assessed cases followed a government action. ${ }^{64}$ They showed that follow-on cases deal with more serious infringements and lead to greater sums of recovery. Kauper and Snyder proved that stand-alone claims do not take longer than follow-on actions nor were they less successfully litigated. However, settlement rates were higher for cases that succeed a government decision. Overall, the study revealed that 90 per cent of all US antitrust

\footnotetext{
${ }^{61}$ William Breit and Kenneth G Elzinga, 'Private Antitrust Enforcement: The New Learning' (1985) 28 Journal of Law \& Economics 405; Thomas E Kauper and Edward A Snyder, 'An Inquiry into the Efficiency of Private Antitrust Enforcement: Follow-on and Independently Initiated Cases Compared' (1986) 74 Georgetown Law Journal 1163; Steven C Salop and Lawrence J White, 'Economic Analysis of Private Antitrust Litigation' (1986) 74 Georgetown Law Journal 1001; White (ed) (n 25).

62 Kenneth G Elzinga and William C Wood, 'The Costs of the Legal System in Private Antitrust Enforcement' in Lawrence J White (ed), Private Antitrust Litigation: New Evidence, New Learning (MIT Press, Cambridge Mass. 1988).

${ }^{63}$ Jeffrey M Perloff and Daniel L Rubinfeld, 'Settlements in Private Antitrust Litigation' in Lawrence J White (ed), Private Antitrust Litigation: New Evidence, New Learning (MIT Press, Cambridge Mass. 1988).

64 Thomas E Kauper and Edward A Snyder, 'Private Antitrust Cases that Follow on Government Cases' in Lawrence J White (ed), Private Antitrust Litigation: New Evidence, New Learning (MIT Press, Cambridge Mass. 1988).
} 
enforcement between 1973 and 1983 was based on civil actions brought by those who allegedly suffered a loss from the breach of the antitrust rules. ${ }^{65}$

Lande and Davis assessed 40 antitrust cases in a more recent study. ${ }^{66}$ The aim of their project was to show the financial benefits of private antitrust enforcement. The data did not include cases that were concluded before 1990 or produced a cash value of less than $\$ 50$ million. The authors also excluded proceedings which, for instance, were lost, appeared to be difficult or time-consuming, or in which the precise monetary value of the case could not be specified. Lande and Davis stressed that the deterrent effect of private enforcement is significantly higher than the deterrent effect of criminal enforcement of the Department of Justice.

While a considerable amount of information about US private antitrust enforcement is available, few data has been gathered and assessed in Europe. A comprehensive and systematic study of private enforcement of competition law was conducted by Barry Rodger who analysed civil litigation in the UK until 2008. ${ }^{67}$ His research was based on the two main legal databases from which he extracted detailed information about statutory provisions, anticompetitive behaviour, parties, and outcome in cases in which an infringement of European and UK competition law was claimed before UK courts. He observed that in recent years the number of competition law issues that were brought by plaintiffs increased compared to cases in which a competition law defences was raised. Rodger believes that "[...] the absence of developed procedural and substantive rules appears to be both a cause and effect of settlement practice, and is arguably restricting, discouraging and disincentivising appropriate competition law claims." 68 Empirical research on antitrust settlements in the UK, which was also undertaken by Rodger, suggests that allegations of abusive conduct play an important role in private

\footnotetext{
${ }^{65}$ Steven C Salop and Lawrence J White, 'Private Antitrust Litigation: An Introduction and Framework' in Lawrence J White (ed), Private Antitrust Litigation: New Evidence, New Learning (MIT Press, Cambridge Mass. 1988).

${ }^{66}$ Robert H Lande and Joshua P Davis, 'Benefits From Private Antitrust Enforcement: An Analysis of Forty Cases' (2008) 42 U.S.F.L.Rev. 879.

${ }^{67}$ Rodger (n 13); Rodger (n 13).

${ }^{68}$ Barry J Rodger, 'Competition Law Litigation in the UK Courts: A Study of all Cases 2005-2008, Part II' (2009) 2

Global Competition Litigation Review 136, 147.
} 
competition law cases. According to Rodger, the majority of competition law disputes in the UK were settled out of court before a final judgement on the merits was made. ${ }^{69}$

The lack of knowledge about the real extent and nature of private antitrust enforcement becomes obvious if one looks at other European (civil law) jurisdictions for which no comprehensive and systematic studies exist to date barring anecdotal evidence. ${ }^{70}$ Even the two major studies commissioned by the European Commission do not shed much light on the nature of private enforcement of the national and EU competition rules. The Ashurst Study, ${ }^{71}$ instructed by the Commission in 2004, was carried out in order to identify the obstacles to successful damages actions for the infringement of $E U$ competition law. Primarily comparing the conditions for compensatory antitrust claims in 25 Member States, the authors also collected information about the volume of antitrust litigation. The study revealed around 60 judged damages cases for damages actions of which 12 were decided on the basis of EU law, around 32 on the basis of national law and six cases dealt with both EU and national law. 28 judgements had resulted in an award being made at the time of the study. As for Germany, Ashurst singled out 159 competition law proceedings (all remedies) between 1999 and 2004 of which 119 led to a court decision. 27 per cent of those 119 German cases were awarded and 45 per cent dismissed on the merits. The remaining cases were interim proceedings and cases with an unknown outcome. Interestingly, 93 (80 per cent) of the 119 cases were exclusively based on alleged violations of German competition law. ${ }^{72}$ Although the authors of the Ashurst Report warned of the limited explanatory power of their study, this warning has been mostly ignored in subsequent debates. ${ }^{73}$ The empirical research undertaken by Ashurst with respect to private antitrust cases was probably the first of its kind in Europe. However, Ashurt's empirical work suffered from two drawbacks. First, for their final comparative report the authors considered only damages actions which were

\footnotetext{
${ }^{69}$ Rodger (n 13).

${ }^{70}$ See, for instance, Böge and Ost Konrad (n 14).

${ }_{71}$ Waelbroeck, Slater and Even-Shoshan (n 12).

72 Denis Waelbroeck, Donald Slater and Gil Even-Shoshan, Study on the Conditions for the Claims of Damages in Case of Infringement of EC Competition Rules: National Report Germany (Brussels 2004).

73 "It should be underlined here that the figures [...] only reflect the actions which the present study has revealed and should in no way be considered to give a complete picture of litigation in this area in the different Member States." Waelbroeck, Slater and Even-Shoshan (n 12) 100.
} 
based on the violation of EU competition law ignoring all instances in which cases for the violation of national antitrust law were brought or other than damages remedies were requested. Second, gathering information about antitrust cases in Germany, the national rapporteurs asked courts whether they know about competition law litigation in their jurisdictions. This approach assumed the existence of sufficient resources to reply and relied on the willingness to respond which was low. ${ }^{74}$ Of the 42 courts approached, eight did not reply at all. Only six courts and the Federal Court of Justice (BGH) answered the survey thoroughly. The method also implied that the courts were actually aware of competition law claims and classified them accordingly. With the focus on damages actions for the violation of Articles 101 and 102 the study concluded that the number of successful claims was low.

More recent real-world data was provided by the Welfare Impact Report of 2008, underpinning the European Commission's White Paper from the same year. ${ }^{75}$ Relying on the Commission's data collation and reports from the Member States, the Impact Report identified 96 antitrust damages actions in the EU27. The Impact Report did not include litigation solely based on the violation of national competition laws. It states that there has been a growth in the number of private antitrust cases per year since the Ashurst Study was published. However, no successful EU law damages action was reported. Follow-on actions, which had been initiated after an authority handed down a decision, clearly dominanted according to the Impact Report. Sarra and Marra used a different source for their analysis of obstacles to private enforcement relying on suits that were reported to the e-competition database. ${ }^{76}$ They found that of the 36 proceedings they identified in the Member States many antitrust cases are brought on the back of previous courts' judgements or authorities' decisions. In their view, actions for damages are often rejected or dismissed for the lack of evidence. ${ }^{77}$

\footnotetext{
${ }^{74}$ Waelbroeck, Slater and Even-Shoshan (n 73) 30.

${ }^{75}$ Renda and others (n 11).

${ }^{76}$ Alessandro Sarra and Alessandro Marra, 'Are Monetary Incentives Enough to Boost Actions for Damages in the European Union? On the Relevance of Incompleteness of Laws and Evidentiary Requirements' (2008) 31 World Competition 369.

77 ibid. 374.
} 
Subsequent to the publication of the Ashurst Report, the German Federal Cartel Office (FCO) published German litigation data on two occasions challenging the dominant notion of underdevelopment. In its discussion paper on private enforcement of competition law the FCO stated that the courts register several hundreds proceedings each year. ${ }^{78}$ For the time period between 2002 and 2005 the FCO counted around 900 civil cases. Explaining the year 2004 in more detail, the FCO found 240 civil disputes. 56 of these proceedings were decided under German competition law with 20 cases won and 36 lost. The violation of European law was brought forward in 12 proceedings with three cases won and nine lost. Damages were considered in 38 judgements and awarded in 19 proceedings. The 2004 data showed that plaintiffs mainly alleged vertical restraints and unilateral conduct while actions against hard-core cartels were rarely brought. The FCO concluded that private antitrust enforcement is an integral part of enforcement in Germany. ${ }^{79}$ A similar claim was made by the then president of the FCO who stressed that private antitrust enforcement does play a role in the German setting. ${ }^{80}$ In his view, most private enforcement cases in Germany do not involve hard-core cartels. Private litigation complements public enforcement as the competition authorities would be overburdened if they had to take up each case of, for instance, unjustified refusal to supply. ${ }^{81}$

\subsection{Preliminary conclusion}

In the last decade, decision makers in Europe and the Member States discovered the importance of private antitrust enforcement. The late discovery was followed by intense action to improve the conditions for antitrust damages actions. It is probably correct to assume that a glance at the US developments has sparked and shaped the legislative proposals of the European Commission. However, the proposals may have overlooked the particular setup in the Member States. As for its main assumption of underdevelopment, the reform could stand on rather shaky ground. All proposals and most of the discussion are based on the assumption that private antitrust enforcement

\footnotetext{
${ }_{78}^{78}$ Bundeskartellamt (n 33).

${ }^{79}$ ibid. 4.

${ }^{80}$ Böge and Ost Konrad (n 14).

81 Böge (n 29) 115.
} 
in general, and private damages actions for the breach of EU competition law in particular are completely underdeveloped. This assumption lacks systematic evidence for most Member States though. Little is known about the real number of cases, the nature of private actions, the origin thereof or the competition law provisions involved. The often made comparison with the US probably obfuscated the fact that the procedural systems on both sides of the pond differ significantly from each other. Furthermore, while the nature (mostly damages actions) and the number of claims in the US is relatively well known, the state of private actions in Europe is unknown for most parts. We do not know how many cases involving both national and European law exist, which remedies they deal with (are they mostly damages claims?) and in which context antitrust issues are raised. While commentators in the US agree that private antitrust litigation is a major component of the overall enforcement scheme, there is less consensus about the role of private actions in Europe. The majority of stakeholders focuses on damages actions and concludes from a lack thereof that private enforcement is underdeveloped in the European Union. ${ }^{82}$

Not only on EU level, but also in Germany, it is frequently asserted that private antitrust is underdeveloped. ${ }^{83}$ Without reference to empirical evidence, private antitrust enforcement is said to be of no significance. At the same time, the Federal Cartel Office asserts that private parties do enforce competition law and that those activities supplement public enforcement. ${ }^{84}$ It is probably fair to assume that the actual state and volume of private enforcement in Europe and in Germany is contentious and, to a certain extent, simply unknown. Only in the UK has a systematic and comprehensive study illuminating the volume of private competition law cases been undertaken so far.

\footnotetext{
${ }^{82}$ Roger van den Bergh and Sonja Keske, 'Private Enforcement of European Competition Law: Quo Vadis?' [2007] 3 European Review of Contract Law 468; Möschel (n 33); Eilmansberger (n 29); European Commission, White Paper (n 9); Cook (n 23).

83 Hempel (n 19); Alexander Fritzsche, 'Der Beseitigungsanspruch im Kartellrecht nach der 7. GWB-Novelle, Zugleich ein Beitrag zur Dogmatik des quasi-negatorischen Beseitigungsanspruchs' (2005) Wettbewerb in Recht und Praxis 42; Möschel (n 33); Logemann (n 33).

${ }^{84}$ Böge (n 29) 115.
} 


\section{The study - design, data collection and limitations}

The previous section showed that we know relatively little about the nature and magnitude of private actions in Germany and Europe. In this section I will outline the study's objective, the design and the information used to compile the dataset on German private antitrust. As with all empirical work there are some limitations which I will explain too.

The major aim of this study was to find out how many and what type of private antitrust actions are brought before German courts. The wide-ranging statements about the amount of litigation ranging from "underdeveloped" to "being an important part of the enforcement scheme" motivated this research. Unlike the studies that were conducted at the European level, this project was not confined to damages actions for the breach of EU competition law. It follows a wider approach because the law provides more than just damages claims to remedy the violation of competition law. The data includes the alleged breaches of both European and German competition law. Going beyond the mere volume of proceedings, I included inter alia the following questions: which antitrust breaches are predominantly privately pursued? Do private actions follow public decisions or are they mostly brought independently? What types of plaintiff competitors, direct customers or consumers - are most likely to bring actions? In which industries do private actions occur more frequently?

At the outset, I sought information about the courts, the date of the decision and whether the claim was brought independently or followed by a public investigation. The primarily and secondarily sought remedies were looked for as well as the outcome of litigation. Further variables covered counterclaims, the amount of damages, the primarily and secondarily violated statutory provisions, the primarily and secondarily alleged anticompetitive behaviour, the business relationship between the parties, the market shares of the parties or, in the absence of market share data, a rough estimation of the plaintiff's size. Plaintiffs can bring forward more than one remedy request based on various allegations of breaches of the antitrust rules. Referring to the primarily and 
secondarily remedy, statute or antitrust violation respectively, I tried to collect information about cases in which multiple requests or multiple allegations were made. Primarily and secondarily refers to the order of remedy requests or allegations. Furthermore, I tried to learn more about the affected industry and whether the case was decided by an appeal court. Unfortunately, information about the size of the parties, market shares or the size of damages awarded proved untraceable or so patchy that I decided not to include the data in my analysis. As for the size of the damages award anecdotal evidence exists for some proceedings.

The initial data for this study stemmed from the FCO. The FCO holds basic information about private antitrust proceedings which are conveyed by the courts. According to section 90(1) ARC courts are obliged to notify cases to the FCO in which a dispute arises out of the application of either European or German antitrust law. ${ }^{85}$ The FCO's data are the most but not entirely complete compilation of German antitrust litigation. A central database or register from which one could extract information about actual or past cases does not exist. Judges are not bound to publicise their decisions and it is normally in their discretion to communicate rulings which they deem to be of public interest. Consequently, even commercial databases are by no means complete. This reporting deficit does not create difficulties with respect to larger or contentious antitrust cases as they are most likely to be publicised but it seriously affects ordinary disputes because of the lack of public interest. To a certain extent, the notification duty in section 90(1) ARC helps to overcome this problem. However, notwithstanding the notification duty some proceedings are not notified or only after the judgement was made. There are also instances in which the notification reports are delayed and have to be chased down by staff of the FCO.

The access to the FCO's data was limited for confidentiality reasons. Anonymised lists of decisions - not cases - provided the basis for my dataset. In the decision lists

\footnotetext{
85 The notification system has been in existence since the ARC came into force in 1958 and indicates that private enforcement was always being thought of as one pillar of antitrust enforcement. Providing the FCO with information about pending cases, the legislative intent was to enable the FCO to exercise the public interest submitting statements or pointing out evidence or facts.
} 
parties' names and other classified information was blacked out. The lists contained fewer details than the FCO's electronic 'case information system'. The printouts only summarised court decisions including information about the court, decision date, record number, and a very basic description of the case. No data was available other than for law suits terminated by decision due to the nature of the decision lists. ${ }^{86}$ This affects cases that were settled or in which the claim was not admitted in the first place. Furthermore, pre-trial settlements do not appear before the courts and settlements made during trial are not normally publicised because the judge is discharged from the duty to write a decision and the agreements usually contain a confidentially clause. Therefore, the following analysis is restricted to concluded cases.

The manual data collection took place at the FCO's seat in Bonn in October $2008 .^{87}$ The gathered information covers the years 2005 to 2007. Especially the manual data input significantly slowed down the collection process. The initially compiled data contained many missing values and required a review of more than half of the data points with information from publicly available legal databases, namely juris, ${ }^{88}$ beck-online, ${ }^{89}$ and court databases of some federal states. ${ }^{90}$ The verification process revealed another 57 decisions indicating that the FCO's decision lists were not complete. ${ }^{91}$ It is likely that there are still undiscovered proceedings due to unreported or unpublicised cases and information bottlenecks at the courts.

Having verified numerous data points with the available case law, the database was subsequently adjusted excluding all decisions that were made prior to 2005 and after 2007. Cases that were clearly no private antitrust litigation were eliminated, too. For the

\footnotetext{
${ }^{86}$ During a recent visit at the FCO I gained access to the electronic database which contains very detailed information.

${ }^{87}$ The author would like to thank the FCO for enabling this study. He is especially grateful to Dr. Stephanie Brinster who supported this project.

88 http://www.juris.de/.

$89 \frac{\mathrm{http}: / / \text { beck-online.beck.de/. }}{\text { horth Rhine-Westpha: }}$

90 North Rhine-Westphalia: http://www.justiz.nrw.de/RB/nrwe2/index.php; Hessen: http://web1.justiz.hessen.de/migration/rechtsp.nsf/Intro?OpenForm; Rhineland-Palatinate:

http://cms.justiz.rlp.de/justiz/nav/704/70479ed1-9880-11d4-a735-0050045687ab.htm; Baden-Württemberg: http://lrbw.juris.de/cgi-bin/laender rechtsprechung/list.py?Gericht=bw\&Art=en; Hamburg: http://lrha.juris.de/cgibin/laender rechtsprechung/ha frameset.py?GerichtName=.

${ }^{91}$ The FCO made all relevant decisions from 2005 to 2007 available. A data processing backlog cannot be excluded though.
} 
purpose of this study private enforcement refers to individually initiated litigation, either as stand-alone or follow-on action, before a court to remedy an infringement of antitrust law. ${ }^{92}$ If successful, the legal action leads to some sort of civil sanction such as damages, restitution, injunction, nullity or interim relief. ${ }^{93}$ Individual efforts to support administrative proceedings against a violator of competition law are not aimed at a civil sanction and, therefore, not an element of private enforcement of competition law. ${ }^{94}$ All civil law cases in which a competition law issue was raised either on part of the defendant or on part of the claimant were regarded as private antitrust case. Initially, that included even those cases in which competition law was not explicitly mentioned in the judge's reasoning. Complaints and appeals against public decisions of the FCO that are exclusively handled before the Higher Regional Court of Düsseldorf (complaint instance) and the Federal Court of Justice (appeal instance) were excluded. ${ }^{95}$ Although both courts are civil law courts, the complaints are not ordinary civil law claims or private enforcement cases. The complaints aim at the annulment of an authority's decision (administrative act) and are not directed at a private remedy. Public procurement cases, being dealt with in sections $97 \mathrm{f} A R C$, were excluded as well as unfair competition law litigation. The latter is regulated in the Act Against Unfair Competition and was easy to separate from actions dealing with EU and German antitrust law. The study ignored state aid litigation which generally falls within the scope of the Act Against Unfair Competition. ${ }^{96}$

\section{Results of the study}

This section presents the results from my study. Subsection one explains the number of cases found and their distribution over time. Part II discusses follow-on and stand-alone claims. Characteristics of the parties like, for instance, their business relationship and

\footnotetext{
92 Karen Yeung, 'Privatizing Competition Regulation' (1998) 18 Oxford Journal of Legal Studies 581, 583.

${ }^{93}$ Assimakis P. Komninos, EC Private Antitrust Enforcement - Decentralised Application of EC Competition Law by National Courts (Hart, Oxford 2008) 1.

94 ibid. 583.

95 The record numbers indicate whether the case is a complaint or civil antitrust litigation.

${ }^{96}$ State aid cases were provisionally defined as "[...] action[s] by a (national, regional or local) public authority, using public resources, to favour certain undertakings or the production of certain goods [...]". http://europa.eu/scadplus/glossary/state aid en.htm (last accessed on 10 March 2009).
} 
industry are dealt with in part III. Part IV offers information about the remedies and the use of competition law as offensive "sword" or defensive "shield" litigation. Following the description of the remedies, I will outline the outcome of the claims in part V. Plaintiffs' allegation of anticompetitive conduct and breached statutory provisions are presented in subsections VI and VII. Finally, subsection VIII provides an approximation for the lengths of the different types of private antitrust proceedings.

\subsection{Number of cases}

The initial search and subsequent data cleansing revealed 368 private antitrust cases dealt with before German courts from 2005 to 2007. Presumably, this number is an understatement and must be interpreted with caution. 368 proceedings are likely to be the lowest bound for private antitrust litigation based on the most conservative assessment of the decisions provided by the FCO. We can assume that the actual number of cases is significantly higher for two reasons. First, this dataset does not contain cases that were finished with other than a judgement on the merits. Especially settlements, dropped or dismissed claims are very likely to increase the number of cases if we had information about them. ${ }^{97}$ Second, for several cases the competition law issue in question could not be determined and those proceedings were left out of the analysis. In some cases I could not obtain an electronic copy of the judgement in order to clarify the competition issues. Other verdicts did not reveal the alleged competition law violation in the reasoning although it had probably been brought forward in the first place. Given that the special jurisdiction of regional courts and, thus, the notification duty is already triggered by claimants alleging an antitrust issue, we only know that a competition law problem was raised at some point during the proceedings. ${ }^{98}$ In those cases I assumed that an antitrust allegation had been initially pleaded but was dropped at a later point or turned out to be no longer important for the judge's decision.

\footnotetext{
${ }^{97}$ I am currently analysing the data from stemming from a sequel to this first study. Based on proceedings which were notified to the FCO, the new dataset includes settled, dismissed or otherwise concluded cases. A very cursory count of the proceedings in this new dataset revealed that 1203 antitrust cases were notified between 2004 and 2009. This number does not include some "open" cases and files with missing information and, thus, should be treated with caution.

${ }_{98}$ Assumed that claiming a violation of competition law is cost neutral for the plaintiff and legal costs only occur if evidence to sustain the antitrust claim is required, plaintiffs may initially trigger a competition law case without pursuing it further. It seems to be common German legal praxis to allege all imaginable violations of law in the first place even if they are only remotely relevant.
} 
Only the court records could tell us more about the pleadings of the parties. However, there is no access to confidential court files including parties' statements which would provide more details. In cases where no or very little additional information could be extracted from other sources, I excluded the decision from further analysis. For this reason, 368 cases mark the absolutely lowest bound while further research already undertaken indicates that the number of cases oscillates roughly between 150 and 250 per year.

The complete dataset is based on information from the highest court decision in each case. If, for instance, the parties did not appeal a first-instance judgement, this decision determined the outcome of the case for the purpose of this study. Likewise, if a firstinstance ruling was appealed, the information from the appeal judgement was used to determine the nature of litigation. First instance verdicts and appeal decisions addressing the same parties and the same subject matter were counted as same cases whereby only the substantive assessment of the appeal decision was taken into account. ${ }^{99}$ First instance litigation refers to cases that are dealt with by the regional courts. All cases in which competition law is applied, even if the only question is whether or not competition law is applicable, are exclusively assigned to the regional courts, ${ }^{100}$ the second tier in the hierarchy of ordinary courts. Decisions of the regional courts can be appealed to the higher regional courts and, on points of law, to the Federal Court of Justice (BGH). I cannot exclude that some cases were reviewed after 2007 and the decisions I present as final were later overruled or confirmed. The database reflects that state of all proceedings with decisions on the merit as of 31 December 2007.

\footnotetext{
${ }^{99}$ I cannot fully exclude an element of double-counting in my database. However, since all cases were doublechecked with available legal databases, I believe there is only a very small margin of error if any. The uncertainty is mainly caused by the fact that the data from the FCO's consisted of anonymised summaries of rulings without a track record, details concerning appeals or previous first instance rulings. Therefore, a potential relation between different decisions in the database had to be established at a later stage of this study. As the amount of information publicised by courts varies greatly, this may be the source of some error. Especially regional courts do not report comprehensively or may not be aware of the notification duty at all.

${ }^{100}$ Section 87 ARC.
} 
Table 1: Private antitrust cases per year 2005-2007

\begin{tabular}{ccccc}
\hline Year & Cases total & First instance (\% year) & Appeal (\% year) & Appeal to BGH* (\% per year) ${ }^{\dagger}$ \\
2005 & 147 & $79(54 \%)$ & $59(40 \%)$ & $9(6 \%)$ \\
2006 & 131 & $63(48 \%)$ & $60(46 \%)$ & $8(6 \%)$ \\
2007 & 90 & $38(42 \%)$ & $45(50 \%)$ & $7(8 \%)$ \\
Total & 368 & $180(49 \%)$ & $164(45 \%)$ & $24(7 \%)$ \\
\hline
\end{tabular}

* Federal Court of Justice (BGH) is the highest appeal instance.

† Complaints against denial of leave to appeal were not included.

The data revealed 180 cases that ended in the first instance and 188 cases which were concluded at the appeal stage including 24 proceedings before the Federal Court of Justice (BGH), the highest ordinary court. It appears that parties, once they decide to litigate, regularly appeal first instance rulings. However, the numbers in Table 1 may exaggerate the ratio of first instance rulings and appealed cases. Cases that ended with a regional court verdict are less likely to be publicised than cases from higher regional courts. It is more probable to learn about a case if it reaches the appeal stage. Higher regional courts seem to notify more reliably than regional courts. Sometimes higher courts report more cases than lower courts in their respective district which does not make sense as all cases start at regional court level. There were cases in which the FCO appeared to be informed about ongoing antitrust litigation when parties entered the appeal stage. In those cases only proceedings subject to review would appear in the FCO's list of decisions. This may have distorted the ratio of first instance and appeal proceedings. With regards to appeals, it is interesting to note that since 2002 higher regional courts must explicitly grant leave to appeal their decisions on questions of law before the Federal Court of Justice. Appeal must be granted if the matter is of principal importance, it is required for the development of the law or to safeguard the consistency of the case law. ${ }^{101}$ Parties can file a complaint if the leave to appeal has been denied. The reporting of those complaints - which are not included as they are not decisions on

\footnotetext{
${ }^{101}$ Section 543(2) Civil Procedure Code.
} 
the merits - is very fragmented. Only some complaint decisions appear in public domain, especially if they are successful and raise an important question of law.

Table 1 indicates a drop of cases in 2007 although the date of the decision is a rather poor proxy for measuring the distribution of proceedings over time. It would be more precise to use the date on which the law suit was filed. The date of decision is influenced by the process duration which again is subject to the court's workload, the parties' pleadings, and the degree of factual and legal difficulties. However, in the absence of precise information about the starting point, it is the only available time proxy. In order to obtain a picture of the case distribution all decisions were grouped according to the month in which they were made. Three decisions for which the exact date was unknown were excluded. ${ }^{102}$ Due to the relatively short observation period it is difficult to assess whether the number of private antitrust actions is actually shrinking or we only observe a reporting backlog. The latter seems to be more likely though.

\footnotetext{
${ }^{102}$ For three verdicts in 2005 the exact decision date could not be ascertained.
} 
Figure 1

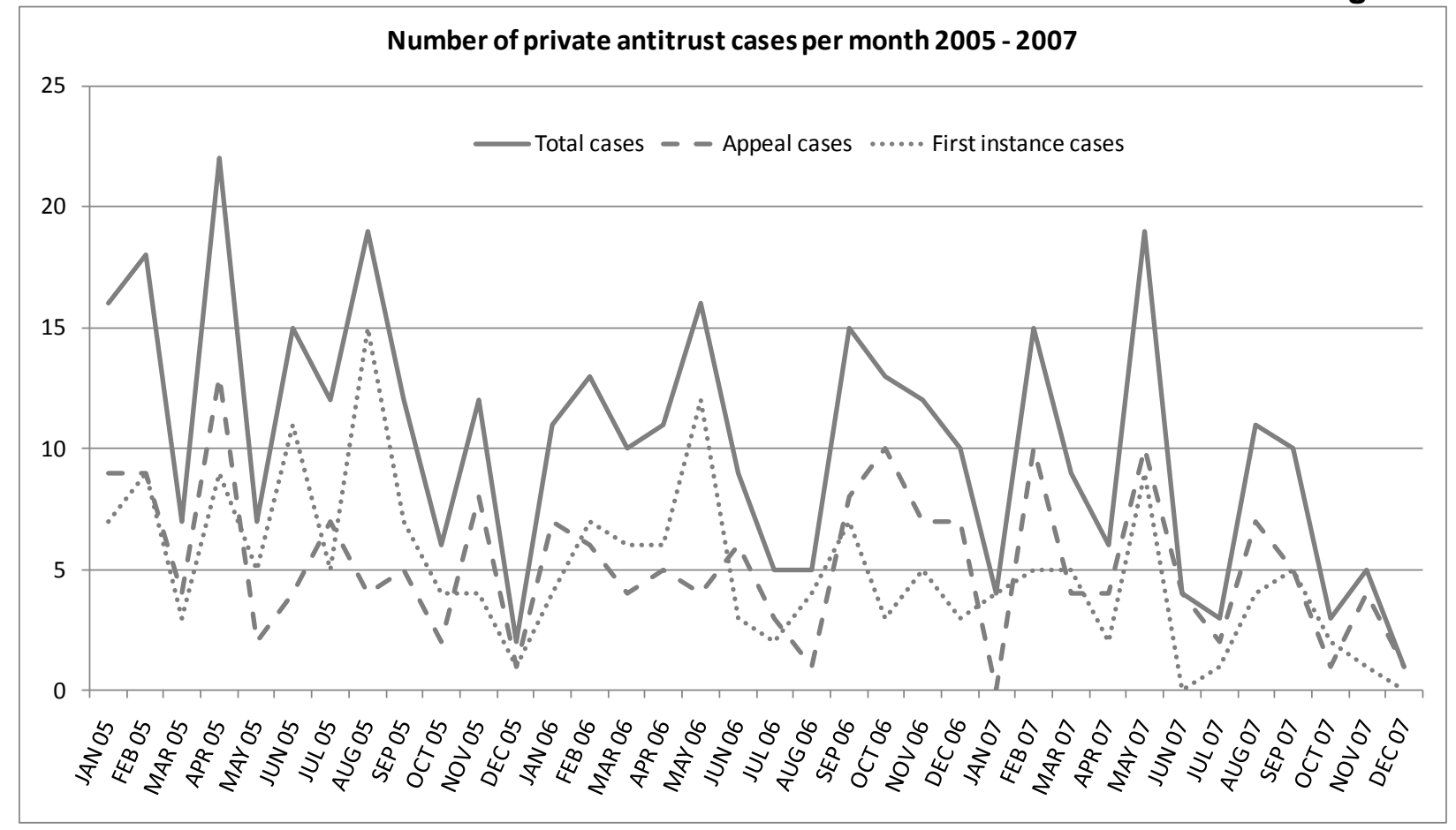

The line chart in Figure 1 indicates a trend towards less competition law litigation. However, if that holds true, it would mean that private enforcement came to a complete halt towards the end of the 2007. It is more likely that this downward swing is caused by a reporting backlog and the publicising problems described above. The particular difficulties of gathering information about regional court law suits may be a plausible explanation for the decline. The fraction of cases decided in first instance and those that went on to the appeal stage changed from 46 per cent appeal cases in 2005 to 58 per cent in 2007. This reflects the drop of regional court proceedings from 79 (2005) and 63 (2006) to 38 (2007). The number of appeal procedures only decreased in 2007 (from 68 cases in 2005 to 52 decisions in 2007). Although one cannot exclude the possibility that fewer cases have been initiated, it does not seem unlikely that the way in which decisions are communicated might have caused the observed decline. ${ }^{103}$

\footnotetext{
${ }^{103}$ This is also confirmed by the new litigation data I gathered recently (see footnote 97). From what I can see so far, there is no evidence for a significant drop of cases at the end of 2007.
} 
The drop of antitrust litigation is counterintuitive if we take into account the 2005 amendment of German competition law improving the conditions for individual antitrust claims. Decisions of other EU national competition authorities became binding in followon damages law suits and the "protective law" requirement, narrowing the standing for antitrust actions, was abolished. ${ }^{104} \mathrm{~A}$ decline of litigated cases is at odds with the plaintiff-encouraging amendments in the ARC. If we allow for an unknown number of settlements, which may have increased in the course of and after the reform, and an improved deterrence effect, the drop in litigated cases makes a little bit more sense. Whether and to what extent the on-going discussion about a more-economic approach for the assessment of anticompetitive conduct has deterred litigation cannot be said. One could argue that if courts require more and (more) sound economic evidence, they burden the plaintiff with additional costs and risks and, thus, may lessen the incentives to litigate. ${ }^{105}$

Apart from the Federal Court of Justice all courts are state courts. The data show that private antitrust cases are not evenly distributed among the federal states. ${ }^{106}$ More than 40 per cent of all cases stem from North Rhine-Westphalia, the economically strongest state and, coincidentally, the state where the Federal Cartel Office has its seat. Bavaria is second (16.3 per cent) followed by Hessen (9.8 per cent) and Baden-Württemberg (7.3 per cent). The data suggest that we observe something like an east-west divide which probably has its roots in the differing strength of state economies. A regression of the gross domestic product per federal state in 2005 against the number of cases in the observation period supports this conclusion. It indicates a positive relationship between economic strength and the number of cases per federal state. ${ }^{107}$ Although the results from the regression are statistically significant they make less sense from an economic point of view. An increase in the number of cases by one would require a growth of GDP per state of more than four billion Euros. In the absence of other more precise

\footnotetext{
104 See for details Roth (n 33).

105 Böge and Ost Konrad (n 14) 205.

106 See Table 1 in Appendix.

107 Number of cases $=-11.32+0.000234$ GDP in Mill

(SE 6.90) (SE 0.00003)

$(P$-value $=0.12) \quad(P$-value 0.00$)$

Observations: 16; R Square 0.76207280484447; $F=44.8415291948798$
} 
indicators like, for instance, the Herfindahl-Hirschman concentration index or the firm size, gross domestic product per federal state provides for an approximated value. According to this estimation, there might be a relationship between the economic situation in a state and the frequency of antitrust cases. The recent biannual report of the German Monopoly Commission supports this argument too. Compiling data from 2008 , the report showed that 21 of the 73 biggest companies, based on domestic added value and with their headquarters in Germany, are located in North RhineWestphalia. ${ }^{108}$ Baden-Württemberg comes second with 16 companies, Bavaria and Hessen share the third place with 11 companies having their seat in these states respectively. In states with no or few reported cases, like Mecklenburg-Vorpommern, Thuringia, Brandenburg, Saxony, Schleswig Holstein and Saxony-Anhalt, no big firm has got its headquarter. ${ }^{109}$ However, there are states with just a handful of reported cases but with some of the 73 biggest firms within their boundaries. For example, the courts from Lower Saxony reported only eight antitrust proceedings notwithstanding the fact that four of the big 73 have their seat there. Similarly, two big firms have their main address in Rhineland-Palatinate which reported eight cases. The allocation of big firms may be another factor determining the allocation of antitrust cases. As the competent jurisdiction for a firm that is being sued is normally determined by the seat and big firms are more likely to be dominant or involved in legal disputes, the headquarters of big firms in Germany may also have influenced the distribution of antitrust cases.

\footnotetext{
${ }^{108}$ Monopolkommission, Mehr Wettbewerb, wenig Ausnahmen: 18. Hauptgutachten der Monopolkommission gemäß $\S 44$ Abs. 1 Satz 1 GWB (Bonn 2010) http://www.monopolkommission.de/aktuell hg18.html (accessed 16 July 2010) 86.

See Table 1 in Appendix.
} 


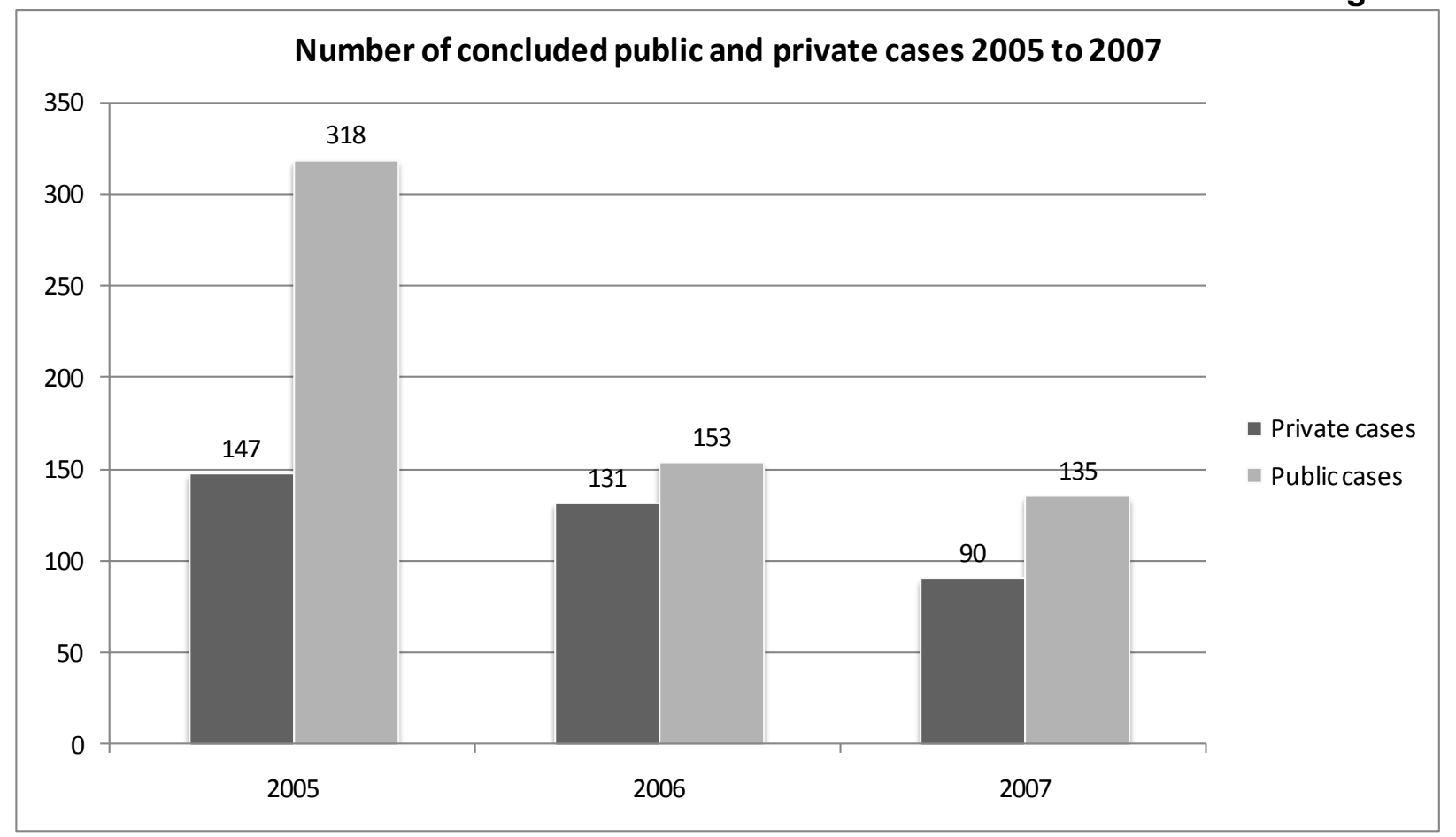

As Figure 2 points out, the 368 private antitrust cases present a significant share of the overall enforcement scheme compared with the enforcement activity of the FCO. ${ }^{110}$ From 2005 to 2007 the FCO commenced a total of 438 proceedings and completed 577 investigations regarding the cartel prohibition, the abuse of dominance and economic dependency. ${ }^{111}$ These numbers include, for instance, administrative procedures aimed at imposing fines, cease and desist orders and other remedies against abusive behaviour. The majority of public proceedings between 2005 and 2007 were either closed or not further investigated as the FCO saw no reason to act. One must note that the FCO usually open a file for each complaint or if it learns about a potential case. Between 2005 and 2007 cease and desist orders and fines added up to 22 formal

\footnotetext{
${ }^{110}$ To simplify matters investigations and decisions of the European Commission, other national competition authorities and the competition authorities of the German federal states are left out of the analysis. The competition authorities of the federal states deal with local and regional infringements of the ARC.

${ }_{111}$ Bundeskartellamt, Bericht des Bundeskartellamtes über seine Tätigkeit in den Jahren 2005/2006 sowie über die Lage und Entwicklung auf seinem Aufgabengebiet (Bonn 2007) Bundestagsdrucksache 16/5710; Bundeskartellamt, Bericht des Bundeskartellamtes über seine Tätigkeit in den Jahren 2007/2008 sowie über die Lage und Entwicklung auf seinem Aufgabengebiet (Bonn 2009) Bundestagsdrucksache 16/13500. The merger control provisions are not privately enforced and were not taken into consideration. The competition authorities of the federal states commenced 1501 antitrust proceedings between 2005 and 2007. Many of those investigations deal with abusive behaviour (pricing) in the energy sector.
} 
decisions. In 84 cases the undertakings concerned ceased the illegal behaviour. At the same time, 368 private antitrust proceedings were concluded. Bearing in mind that the assessment of the magnitude of private litigation is based on the most conservative criteria and does not include settlements, it seems that private antitrust actions play a considerable role in the German competition law enforcement scheme.

Although my data shows that a considerable amount of private cases exist, we should be careful when drawing conclusions from the pure number of cases. Salop and White stated that "[...d]ata on the number of suits initiated, when viewed in isolation, are insufficient to draw conclusions about the effectiveness of deterrence and the extent to which violations are being committed." ${ }^{112}$ Fewer actions may be the consequence of effective deterrence and, thus, indicate fewer breaches. Or it could point towards a low level of deterrence because there are insufficient incentives to bring suits. My data reveals a considerable number of law suits but does not tell us about the frequency of breaches of competition law or the incentives provided for plaintiffs.

\subsection{Stand-alone and follow-on litigation}

If national competition authorities or the European Commission have already investigated an infringement of the antitrust laws, plaintiffs have the opportunity to refer to the results of the public procedure. If plaintiffs follow a public decision, the case is regarded as a follow-on procedure. Needless to say that the follow-on option only exists where a government investigation has been conducted previously. Stand-alone actions are private law suits which are independently initiated and do not follow a public investigation. For the purpose of this study I refer to follow-on litigation if it pursues an identical allegation that was brought forward in a public case or the violation is substantially similar to a previous government action but extends the allegation to different markets, time periods or defendants. ${ }^{113}$

\footnotetext{
112 Salop and White (n 62) 1021.

113 Kauper and Snyder (n 62) 1175.
} 
A preceding government action is said to alleviate the procedural burden that is on victims when they bring their own actions. The binding effect (or prima facie evidence in the US) that is provided for in several jurisdictions facilitates the proof of anticompetitive conduct and makes follow-on actions more likely to occur than stand-alone claims. ${ }^{114}$ In their study on US cases, Kauper and Snyder have shown that follow-on litigation benefits from preceding public efforts in a way that it costs fewer resources and results in higher awards. ${ }^{115}$ Somewhat unexpectedly, follow-on suits do not take less time than stand-alone actions. ${ }^{116}$ At the time of the Georgetown Project, the typical US private antitrust case entered the litigation stage only after a government agency has already convicted the defendant. ${ }^{117}$ This has certainly changed with law suits being filed as soon as an investigation is announced. Potential plaintiffs perceive public investigations as a signal that there must be substantial reasons for public action and thus merits in litigation. ${ }^{118}$ Although the plaintiff relies on preceding government investigation he still has to show that he suffered a loss and that this loss was caused by the violation of an antitrust statute. In contrast, stand-alone cases are deemed to be more complex and difficult because of the lack of easily available evidence. Bearing in mind that the German law provides for a binding effect of public decision, one would expect a considerable amount of follow-on claims in Germany. According to section 33(4) ARC victims benefit from infringement findings made in final decisions of the European Commission, European courts, Member States' courts and competition authorities with regard to damages actions.

Against this background the data show a very low level of follow-on litigation. Only eight cases, or 2.2 per cent of the total sample, followed a prior decision of a competition authority. For four cases, or 1.1 per cent of total, it could not be established whether the plaintiffs referred to a decision of a competition authority. In three proceedings the

\footnotetext{
${ }^{114}$ Ariel Ezrachi, 'From Courage v Crehan to the White Paper - The Changing Landscape of European Private Enfrocement and the Possible Implications for Article 82 EC Litigation' in Mark-Oliver Mackenrodt, Beatriz Conde Gallego and Stefan Enchelmaier (eds), Abuse of Dominant Position: New Interpretation, New Enforcement Mechanisms? (MPI studies on intellectual property, competition and tax law, Springer, Berlin 2008) 118.

115 Kauper and Snyder (n 62) 1169.

116 ibid.

${ }^{117}$ Kenneth G Elzinga and William Breit, The Antitrust Penalties: A Study in Law and Economics (Yale Univ. Press, New Haven 1977) 142.

${ }^{118}$ Kauper and Snyder (n 62) 1165.
} 
plaintiffs followed cartel-related investigations: the German Concrete cartel, the infamous Vitamin cartel and the Carbonless Paper cartel. The Vitamin and Carbonless Paper cartel proceedings were based on decisions of the European Commission. ${ }^{119}$ Admittedly, the Vitamin decision of the European Commission attracted more follow-on damages claims in Germany though they fell outside the observation period because they were mostly concluded in 2003 and 2004. ${ }^{120}$ Interestingly, the Carbonless Paper litigation was initiated and concluded before the Court of First Instance (CFI) finally decided on the cartel members' annulment action in 2007. The German judge held inter alia that even if the defendant participated in the cartel, the plaintiff being an indirect purchaser did not have standing according to the (now outdated) protective law requirement. ${ }^{121}$ While the plaintiffs in both Vitamin and Carbonless Paper litigation requested damages, the plaintiffs in the Cement cartel case merely invoked the voidness of, what they regarded as, a cartel related contract. In the remaining follow-on actions plaintiffs based their claims on the abuse of dominance. In two cases the claimants referred to preliminary findings from an investigation of the FCO. The FCO had probed into allegations of abusive conduct in the telecommunication sector but settled the case after accepting commitments from the undertaking concerned. In three private proceedings the plaintiffs drew on a final FCO decisions in the postal services sector.

In general, private antitrust enforcement in Germany is characterised by independently initiated litigation. This raises the question why litigants do not capitalise more on public enforcement activity. Admittedly, the observation period of only three years does not suffice to explain mid or long-term effects of the binding effect provided for in section 33(4) ARC which came into force only in July 2005. One explanation could be that the binding effect only applies to damages claims which are more difficult to bring than injunctions, for instance, because loss and causation still have to be proven for the former. Therefore, damages actions cause higher costs compared to 'bare' injunctions.

\footnotetext{
${ }^{119}$ Carbonless paper [2004] OJ L115/1 and Vitamins [2003] OJ L6/1.

${ }^{120}$ Landgericht Dortmund WuW/E DE-R 1352 Vitaminkartell; Landgericht Mainz, NJW-RR 2004, 478 Vitaminkartell; Oberlandesgericht Karlsruhe NJW 2004, 2243 Vitaminkartell; Landgericht Mannheim GRUR 2004, 182 Vitaminkartell.

${ }^{121}$ Landgericht Mannheim EWiR 2007, 659.
} 
The possible deterrence effect of the protective law requirement until 2005 may also have influenced the willingness of potential plaintiffs to file actions in the aftermath of public decisions. In fact, before the $7^{\text {th }}$ amendment of the ARC in 2005, the protective law requirement hampered damages actions, for instance, in the carbonless paper and vitamin litigation. Another possible reason why follow-on (damages) actions have not shaped private antitrust litigation yet may be the lack of final public decisions. According to its activity report 2005/2006, ${ }^{122}$ the FCO carried out 298 investigations in 2005 and 2006 regarding the cartel prohibition, the abuse of dominance or the abuse of economic dependency. However, only very few investigations led to a final infringement decision a necessary prerequisite for the binding effect in follow-on damages litigation. ${ }^{123}$ However, there is a third reading of the low number of actually litigated follow-on actions. Since there was a number of cartel cases in both the EU and Germany during the observation period and given that these cases on the whole are easier to litigate because culpability has been established, we would expect a high level of settlements in cases where the defendant's position was weak, leaving the cases where the plaintiff misjudged the strength of the defendant's case to go to court. ${ }^{124}$ In other words, cases where the defendant knows that he is likely to lose are settled before or during trial and, thus, not part of this dataset. ${ }^{125}$ Litigation against defendants who think they have a good chance of fending off the claim is litigated and ends with a decision on the merits. As we know that roughly two thirds of the cases litigated were won by the defendants this may hint towards a follow-on settlement practice. ${ }^{126}$

In general, the high proportion of stand-alone litigation argues in favour of a complementary role of private enforcement as it was claimed by Ulf Böge and Konrad

\footnotetext{
122 Bundeskartellamt (n 112).

123 Similarly, the European Commission concluded only a fraction of all proceedings with a formal infringement decision. Between January 1999 and February 2004 the number of settlements exceeded the number of prohibitions with fines. Jordi Gual and Nuria Mas, 'European Commission Decisions on Anti-Competitive Behavior' [2010] SSRN eLibrary.

${ }^{124}$ Sylvain Bourjade, Patrick Rey and Paul Seabright, Private Antitrust Enforcement in the Presence of Pre-trial Bargaining. Working Paper (Toulouse 2007) 13.

${ }_{125}$ For a similar reason the ratio of stand-alone cases might be exaggerated. Taking into account settlements, followon cases that do not involve difficult legal or factual questions are likely to be settled out of court leaving only difficult proceedings to be determined by the judge. Thus, the real number of follow-on cases would be greater.

${ }^{126}$ For the outcome of the antitrust remedies see under section V.
} 
Ost. ${ }^{127}$ The findings of my study confirm that private enforcers are willing to take up cases which were not investigated by a competition authority. As we will see below, this is reflected in the type of anticompetitive behaviour alleged.

\subsection{Parties involved in antitrust litigation}

The business relationship of the claimants and the defendants was ascertained for the majority of observations. The study identified the relationship from the party's point of view who introduced the antitrust issue. For example, if the initial defendant in a civil law suit asserted an infringement of antitrust to fend off the primary claim, it was the defendant's relationship to the original claimant that mattered. Initially, I tried to identify seven different categories: competitors, dealers or suppliers, customers, franchisees, licensees, final customers or end users and indirect purchasers. If a vertically integrated or diversified undertaking was active in an upstream and downstream market, the subject matter of the legal dispute indicated whether this was litigation between dealer and purchaser or competitors. I do not have information about the number of plaintiffs and defendants in the respective case.

\footnotetext{
${ }^{127}$ Böge (n 29) 115.
} 
Figure 3

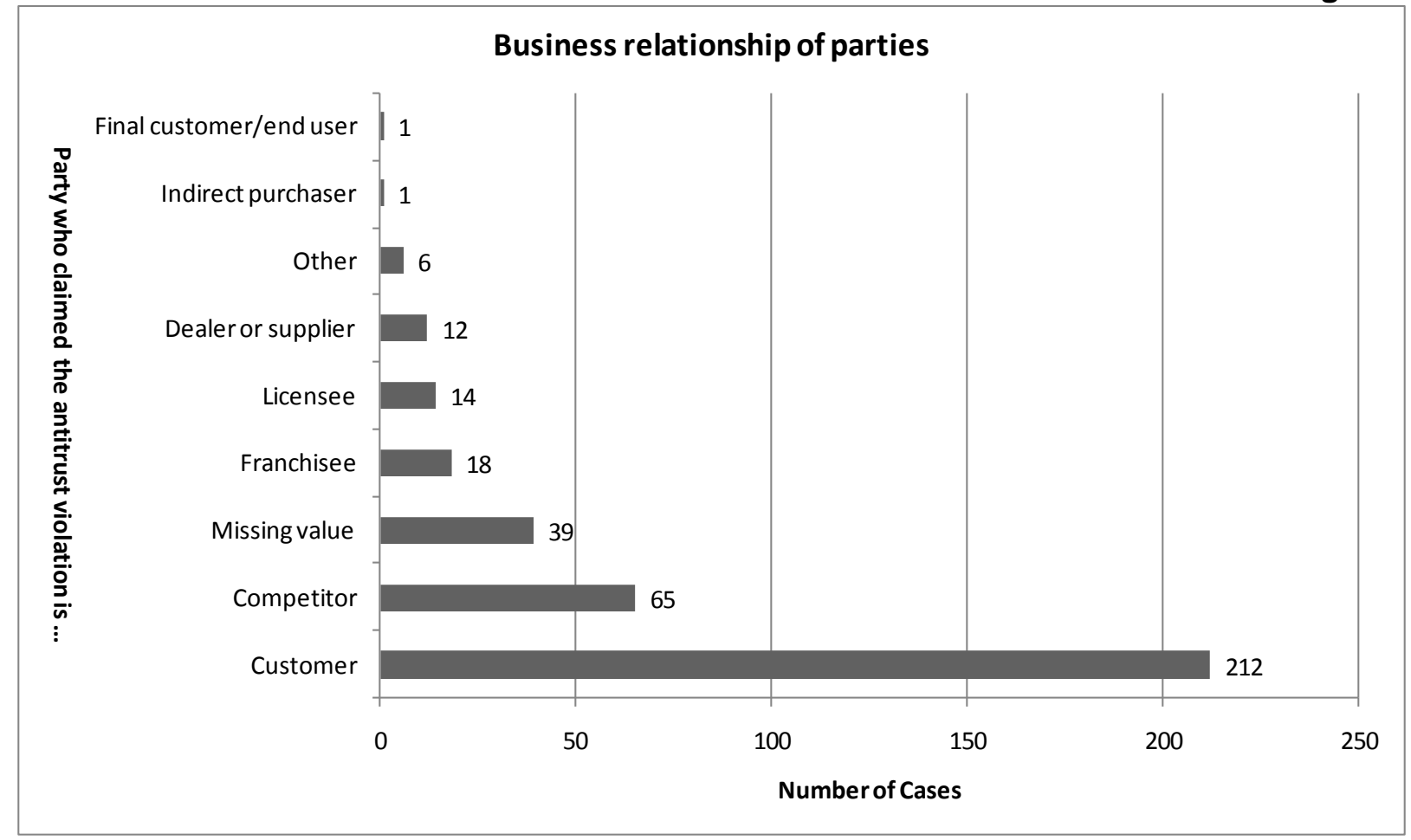

Direct customer claims dominated private antitrust enforcement in Germany between 2005 and 2007 (Figure 3). They accounted for the vast majority of antitrust claimants with 212 proceedings or 57.6 per cent of all disputes. In 17.7 per cent of all cases competitors raised antitrust issues. Franchisees and licensees contributed relatively little to antitrust litigation in Germany. Interestingly, in only one procedure an end user alleged the breach of competition law and only one indirect purchaser claim could be identified - a striking contrast to the United States where consumer litigation exists in the shape of class actions. ${ }^{128}$ According to the Georgetown Study, the biggest groups of competition law plaintiffs in the US in the 1970s were competitors followed by dealers. Consumer actions amounted to nine per cent of all claims. ${ }^{129}$ Admittedly, my data is limited and this hampered the identification of consumers in Germany. But even with some potentially undetected consumer cases the proportion of consumer claims remains low. This result does not surprise. Consumers who want to initiate follow-on

\footnotetext{
${ }^{128}$ Salop and White (n 66).

129 ibid. 8.
} 
claims face, more often than not, a number of problems. First, there is legal uncertainty as to the standing of indirect purchasers. ${ }^{130}$ Second, if they had direct dealings with the perpetrator, the overcharge they paid with their purchase may be too small as to provide a sufficient incentive for costly litigation. Third, if the antitrust violation took place somewhere upstream and consumers did not have direct dealings with the infringer, losses are likely to be passed-on to consumers but will be scattered on the consumer level causing only small individual harm. In addition, the passing-on of overcharges is difficult to prove in each individual case and further diminishes the incentives to sue. Only the aggregated consumer loss is sufficiently large as to provide enough of a stimulus for legal action. In the absence of a class action mechanism which would allow representatives to ask for damages on behalf of the whole class, it is unlikely that a single consumer risks considerable costs to remedy a petty individual loss. ${ }^{131} \mathrm{~A}$ mere binding effect of public decisions does not overcome this incentive problem. Legal actions pursuant to section $34 \mathrm{a} A \mathrm{RC}$ that are aimed at disgorging the illegal profit do not seem to address the issues either. According to section 34a ARC, professional associations have standing to request an account of illegal profits stemming from anticompetitive conduct if a multitude of buyers or sellers were harmed. ${ }^{132}$ However, the illegal profits that are siphoned off the violator must be passed on to the government less expenses. Consequently, professional associations do not normally request an account of profits despite its existence for many years. Unlike the UK where designated consumer organisations have standing to sue on behalf of the victims, ${ }^{133}$ the ARC does not provide for consumer association claims. ${ }^{134}$

\footnotetext{
${ }^{130}$ Rehbinder (n 47) 14; Emmerich (n 47) 29.

${ }^{131}$ But see the CDC cartel claim, which has been admitted by the Federal Court of Justice, introducing a very interesting and new vehicle for collecting scattered losses in Germany. It may not be suitable for petty consumer damage though. See Bundesgerichtshof of 07 April 2009, KZR 42/08.

${ }^{132}$ Those associations must match the criteria laid out under section 33(2) ARC (translation by author): "The claims pursuant to [section 33] paragraph 1 may also be asserted by associations with legal capacity for the promotion of commercial or independent professional interests, provided they have a significant number of member undertakings selling goods or services of a similar or related type on the same market, they are able, with regard to their human, material and financial resources, to actually exercise their statutory functions of pursuing commercial or independent professional interests, and the infringement affects the interests of their members."

${ }_{133}$ Section 47B of the UK Competition Act 1998.

${ }^{134}$ Emmerich (n 47) para 104.
} 
The available data tells us little about the size of the parties. Judges typically omit such information from the verdicts that are publicised because it is deemed to be confidential. Market shares as well as names of the parties were concealed in the lists of decisions I used as a basis for my study. ${ }^{135}$ For the majority of cases in the sample business information was not available. However, the impression prevails that litigation often takes place between small or medium sized companies which may be hint at the use of economic dependency rather than dominance in antitrust proceedings. Another focal point of private antitrust enforcement are actions against former incumbents who are likely to be dominant or nearly dominant. Whether or not economic dependency was used, as denoted by the firm size, also depends on the market definition and, consequently, on the size of the market for which I do not have information. The issue of economic dependency is subject to further research.

For a majority of the decisions I could identify the relevant industry sector. Although it would have been ideal to know the industry for both the defendant and the plaintiff, the nature of accessible information only permitted to identify the industry for the matter in dispute. It means that the industry was determined for the sector in which the violation or the anticompetitive effect had allegedly occurred. This also helped to avoid multiple counts of industries for diversified or vertically integrated undertakings. Based on the UK Standard Industrial Classification of Economic Activities 2007 the study initially distinguished 21 categories. ${ }^{136}$ Antitrust litigation was observed in 14 sectors.

Most cases were observed in the wholesale and retail trade sector which includes the sale and repair of motor vehicles. Admittedly, this industry was defined too broadly and limited the identification of litigation patterns, for example, in the car sector. The wholesale and retail trade sector accounts for 20.1 per cent of all cases. Anecdotal evidence suggests that a considerable part of the litigation in this area stems from or

\footnotetext{
${ }^{135}$ Interestingly, public decisions handed down by the FCO contain names of the parties, legal representatives and a range of market shares.

${ }^{136}$ http://www.statistics.gov.uk/methods quality/sic/downloads/sic2007explanatorynotes.pdf (last accessed on 17 May 2010).
} 
was partly caused by the introduction of Regulation 1400/2002 in October 2003. ${ }^{137}$ Regulation 1400/2002 forced or prompted car manufacturers to review and reorganise their distribution systems. Subsequently, manufacturers let dealer contracts expire or terminated contracts referring to Regulation 1400/2002. Likewise, car dealers who did not want to lose their contracts brought forward their reading of Regulation 1400/2002 and a number of those disputes were taken to court. A superficial search in the database produced 13 cases, or 17.6 per cent of cases in the wholesale and retail sector, in which the plaintiffs or defendants referred to Regulation 1475/95 or $1400 / 2002$.

Table 2: Industry in which the legal dispute took place

\begin{tabular}{|c|c|c|c|c|}
\hline & Industry & Number & $\%$ of total & $\%$ of regulated \\
\hline \multirow{6}{*}{$\begin{array}{l}\text { Regulated } \\
\text { and partly } \\
\text { regulated } \\
\text { industries** }\end{array}$} & Electricity, gas, steam, air conditioning supply & 47 & 12.8 & 34.8 \\
\hline & Information and communication & 44 & 12.0 & 32.6 \\
\hline & Transport and storage & 39 & 10.6 & 28.9 \\
\hline & $\begin{array}{l}\text { Water supply, sewerage, waste management } \\
\text { and remediation activities* }\end{array}$ & 5 & 1.4 & 3.7 \\
\hline & Subtotal for regulated industries & 135 & 36.8 & 100 \\
\hline & & & & $\%$ of unregulated \\
\hline \multirow{13}{*}{$\begin{array}{l}\text { Unregulated } \\
\text { industries }\end{array}$} & $\begin{array}{l}\text { Wholesale and retail trade; repair of motor } \\
\text { vehicles and motor cycles }\end{array}$ & 74 & 20.1 & 44.3 \\
\hline & Manufacturing & 26 & 7.1 & 15.6 \\
\hline & Arts, entertainment and recreation & 21 & 5.7 & 12.6 \\
\hline & Administrative and support service activities & 14 & 3.8 & 8.4 \\
\hline & Construction & 11 & 3.0 & 6.6 \\
\hline & Accommodation and food service activities & 10 & 2.7 & 6.0 \\
\hline & Financial and insurance activities & 5 & 1.4 & 3.0 \\
\hline & Human health and social work activities & 3 & .8 & 1.8 \\
\hline & Other service activities & 2 & .5 & 1.2 \\
\hline & Professional, scientific and technical activities & 1 & .3 & .6 \\
\hline & Subtotal for unregulated industries & 167 & 45.4 & 100 \\
\hline & Missing value & 66 & 17.9 & \\
\hline & Total & 368 & 100.0 & \\
\hline
\end{tabular}

\footnotetext{
${ }^{137}$ Commission Regulation (EC) No 1400/2002 of 31 July 2002 on the application of Article 81(3) of the Treaty to
} categories of vertical agreements and concerted practices in the motor vehicle sector [2002] OJ L203/30. 
* Water industries are only sparsely regulated by the federal states.

** Some unregulated markets appear in regulated industries due to wide sector definitions.

Cases that were brought in regulated and partly regulated industries such as energy, (railway) transportation and telecommunication accounted for more than a third of all proceedings (36.8 per cent of total). In this study, regulated sectors also included legal disputes over postal services which, under the UK Standard Industrial Classification of Economic Activities 2007, were part of the transportation category. Typically, antitrust litigation in regulated or partly regulated sectors is directed against the former incumbent who is likely to operate networks or other essential inputs. For most regulated markets there is a varying degree of ex-ante oversight and ex-post antitrust enforcement. As for postal services, the monopoly of Deutsche Post AG has expired at the end of 2007. The (final) liberalisation of the postal service markets coincides with the end of my observation period. Consequently, litigation in this sector is unlikely to deal with letters but may concern other postal services. The Federal Network Agency (FNA) exercises ex-ante control over grid operators in the gas and electricity sector to ensure that operators do not abuse their local or regional monopolies. However, the FNA does not oversee retail prices for gas and electricity which leaves scope for an expost control through private antitrust litigation and public enforcement by the FCO. The same division of responsibility applies to the telecommunication industry. The Deutsche Telekom AG still enjoys a dominant position in various telecommunication markets but is challenged by rivals. As for competition in the railway sector, the FNA enjoys supervision over railways and regulates the access to infrastructure in order to avoid discrimination. Regulatory oversight in the water sector falls within the domain of the federal states. In general, accusations of unfair pricing or discrimination by final customers or consumers are dealt with under competition law rules despite the regulation in certain sectors.

Especially in regulated industries one would expect litigation from competitors as they are seeking access to the markets which are held by the dominant incumbents. 
Competitors may have incentives to bring actions against discriminatory entry conditions or ask for access to networks and other essential inputs held by the incumbent. At the same time, little competition in upstream markets can lead to higher prices in end user markets if intermediaries can pass on raised input prices. From that perspective, final consumer claims against high prices appear likely although we observed a lack thereof. As for competitor claims, 17.7 per cent of all antitrust allegations were brought by rivals. However, (partly) regulated industries such as transport and storage (30.8 per cent competitor claims) as well as information and telecommunication (47.7 per cent) attracted more private enforcement proceedings initiated by competing firms. ${ }^{138}$ Although the information about the size of the parties is sparse, one could argue that the market entrants utilise litigation means to gain a foothold in markets being characterised by a former monopoly. A similarly high ratio of competitor cases was only observed in the non-regulated construction industry with 45.5 per cent. In the electricity and gas sector customers' claims prevailed with 76.6 per cent within the industry. The high ratio of customer claims coincides with high electricity prices for end users in Germany. Since the Federal Network Agency only controls grid access and charges, the number of customer claims suggests a complementary function of private antitrust enforcement. As we would expect end users to suffer from high energy prices, this may also indicate that the category of customers also contains consumers or end users. The only identifiable consumer action took place in the electricity sector which is well known for its high consumer prices. Customer litigation was also observed in the wholesale and retail industry.

\subsection{Remedies and counterclaims}

This section looks at the remedies that were sought for the violation of European or German antitrust law. Both the plaintiffs and the defendants of the initial law suit may assert a breach of competition law, the former also being referred to as "sword" litigation and the latter being labelled as "shield". At the outset, sword and shield cases were defined as antitrust litigation. However, if the defendant raised the antitrust issues, the case was also marked as being a counterclaim covering real counterclaims for

\footnotetext{
${ }^{138}$ See Table 2 in Appendix.
} 
damages and pure shield defences such as voidness. The categories for remedies used in this study do not reflect the typical classification of claims available under German law. In general, the party affected by the breach of competition law may apply for a declaratory judgement, initiate an action in order to enjoin the other party to refrain from a certain conduct (injunction), ask for removal or request compensation. The following analysis looks mainly at the primarily requested remedies.

Voidness is the only remedy provided for by Articles 101 and 102. The damages remedy or injunctions for a breach of EU antitrust law are safeguarded by the principle of effectiveness. 101(2) TFEU declares any agreement automatically void that violates Article 101(1) and does not fall under Article 101(3). The victim of a horizontal or vertical anticompetitive agreement can invoke the nullity of a contract before court even if he was part of the agreement. ${ }^{139}$ In addition to the European nullity remedy, section 134 of the German Civil Code orders a legal transaction void that violates a statutory prohibition unless the breached statute leads to a different conclusion. Contracts infringing national or EU competition law are normally rendered void under this provision. It is sometimes asserted that particularly defendants use the voidness tool in contract disputes. ${ }^{140}$ All other remedies like damages or restitution are provided for by national laws although Komninos holds the view that the ECJ's Crehan ruling established a community right for damages. ${ }^{141}$ As for injunctions, section 33(1) of the ARC states that if a provision of the ARC or European antitrust law is infringed and the violation found to be illegal, the infringer has to remediate the affected person. If a risk of recurrent infringements exists, which is normally presumed, an injunction will be granted requiring the defendant to do or refrain from doing certain acts. In this study, injunctions comprise of actions that are aimed at stopping an ongoing infringement or target impending violations. ${ }^{142}$ The action to refrain from certain conduct includes both negative duties (to refrain from something) but also obligations such as to further supply the plaintiff. According to sections $935 \mathrm{f}$ of the Civil Procedure Rules plaintiffs can ask

\footnotetext{
${ }^{139}$ Courage Limited v Bernard Crehan (n 6).

${ }^{140}$ Assimakis P Komninos, "Transient" and "Transitional" Voidness of Anti-competitive Agreements: A Non-issue and an Issue' (2007) 28 European Competition Law Review 445.

${ }^{141}$ Komninos (n 5) 167.

142 For the distinction between these two types see Roth (n 33) 1144.
} 
for an injunction by way of interim relief. Interim relief is a preliminary and speedy remedy that, in theory, precludes a decision on the merits. For instance, to ensure that the supply to the plaintiff is continued for the time of the litigation process, the defendant may be forced to uphold deliveries temporarily by way of interim relief. ${ }^{143}$

If the plaintiff seeks monetary relief, there are two alternative means which, depending on the circumstances, he could ask for: damages claims or unjust enrichment actions. Damages are aimed at the compensation of loss suffered from the infringement of competition law and do not include punitive elements as this would be against principle in German civil law. Damages actions do not solely consist of actions for affirmative relief but also incorporate declaratory requests. The latter is appropriate in situations in which the claimant is not yet able to specify the precise amount of damage suffered. In those circumstances the court will determine whether a violation occurred and the claim meets all other conditions apart from the actual amount of loss. Unjust enrichment claims are made under section 812 of the German Civil Code if a person obtains something as the result of the performance of another person without legal grounds. Usually, a contract provides the legal ground for a financial transfer. The party asking for repayment in a competition law context inherently postulates that the legal ground for the transaction is null and void due to an antitrust violation.

${ }^{143}$ Drescher (n 49). 
Figure 4

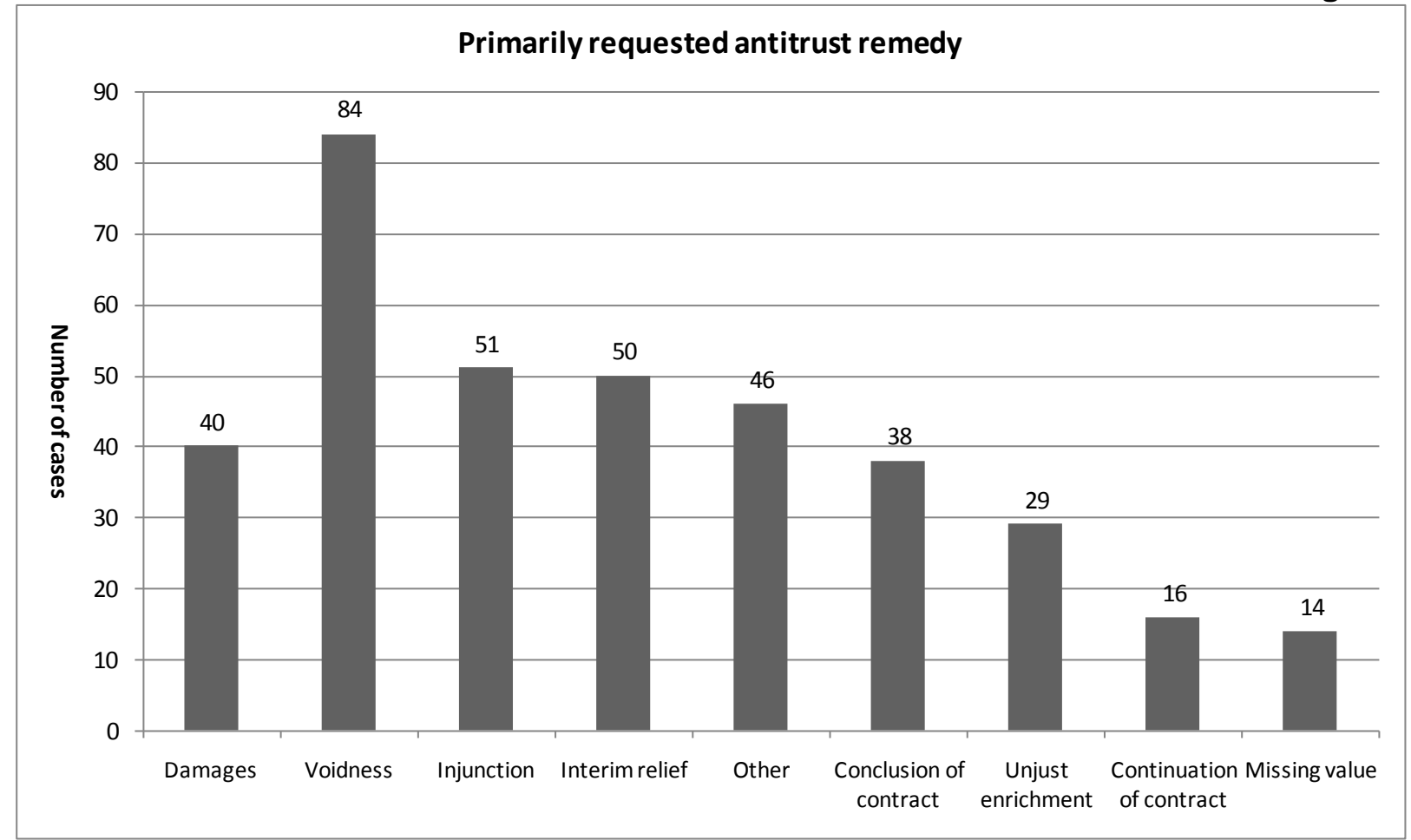

Most frequently, antitrust plaintiffs invoked the nullity of a contract because of the violation of European or German competition law. Voidness requests represented 22.8 per cent of all claims in the sample. Table 3 in the Appendix shows that most of these proceedings were initiated by customers ( 46.4 per cent) followed by competitors (27.4 per cent). Permanent injunctions and interim injunctions were almost equally common with 51 (13.9 per cent) and 50 (13.6. per cent) cases respectively. Damages actions contribute moderately to private antitrust enforcement with 40 cases (11.4 per cent). Customers requested 50 per cent of the damages claims followed by franchisees with five compensation claims (12.5 per cent). ${ }^{144}$ If we add up damages claims and unjust enrichment proceedings which are both aimed at monetary relief, we observe a proportionally large number of cases that actually dealt with pecuniary requests. If we assign the requests to conclude or continue a contract to the injunction remedy, the

\footnotetext{
${ }^{144}$ See Table 3 in Appendix.
} 
number of injunctions increases, too. ${ }^{145}$ I tried to capture the conclusion and continuation of contract separately in order to show that in some instances antitrust disputes arose from previous contracts between the parties (continuation of contract). The conclusion requests indicate that there was no agreement between the parties prior to litigation. In 37 cases I could establish the secondary claim of the antitrust plaintiff. Those were mostly damages requests (18 cases). Ten plaintiffs also asked for various other remedies, three for injunctions, one for voidness, three for conclusion or continuation of contract, and three for repayment because of unjust enrichment.

In a number of cases defendants asserted that the plaintiff violated anticompetitive conduct in order to counter the plaintiff's claim. The term counterclaim was defined broadly comprising of real countersuits and pure defences such as voidness. The data shows that the defendant raised the competition law issues in 91 proceedings (24.7 per cent of all primary allegations). In 79 out of 91 cases defendants referred to the voidness of an agreement in their counterclaim which accounts for 86 per cent of all countersuits. Damages, injunction and interim relief in counterclaims were only sought twice respectively. There were two more instances of counteractions, one in which the claimant made the case for unjust enrichment and one in which the defendant wanted to continue a contract.

Although antitrust damages actions form part of private litigation before the German courts they are not the typical antitrust case. The data does not reveal whether all damages claimants requested precise payments or whether they only sought a declaratory judgement. As requests for declaratory judgements are common in German civil law proceedings, ${ }^{146}$ I anticipated that some of those cases would (re)appear in order for the court to clarify the precise amount of damages. However, the dataset does not reveal cases in which the court established the amount of compensation on the

\footnotetext{
${ }^{145}$ The nature of claims in which the plaintiff requests the conclusion of a contract is contentious. Some argue that the conclusion of a contract is some type of damages remedy without the mandatory fault requirement. Others assert that the request for a conclusion of contract is a removal or injunction claim. For the purpose of this study, I consider it a form of injunctive relief. For an overview see Rehbinder ( $\mathrm{n} 47$ ) 44; Hempel ( 19$) 52$.

${ }^{146}$ Alexander Rinne and Tatjana Mühlbach, 'Germany: Private Antitrust Litigation' [2009] The European Antitrust Review.
} 
basis of a declaratory judgement. This may hint towards a settlement practice which is unobservable in the current data. Another interesting feature of German antitrust litigation is the widespread use of injunctions. However, the frequent employment of injunctions does not entirely fit into a private enforcement system that is said to be primarily aimed at compensation and, maybe, deterrence. We can only speculate why private enforcers prefer injunctive relief and request a "specific performance" from the defendant rather than seeking compensatory payments. It may matter that damages claims are expensive because of the tedious calculation of losses and the difficult proof for causation and harm. But it may also be the case that injunctions satisfy the need for remediation for which plaintiffs are willing to forego uncertain and difficult compensation in exchange for more certain and more immediate relief. It is interesting to note that unjust enrichment claims are used to enforce the antitrust rules too. Since no culpability or loss needs to be established, unjust enrichment is certainly a cheaper remedy than damages actions if the plaintiff's loss consists of a plain and reversible transfer of money. However, unjust enrichment claims inherently postulate the voidness of a contract between the victim and the perpetrator, thus, moving antitrust actions closer to contract litigation. There is probably a considerable overlap between contract and antitrust claims. This is supported by the large number of nullity request which are basically brought to fend off contractual obligations. Whether or not private actions interfere with contract disputes or distort civil litigation cannot be said without further scrutiny of the case law.

\subsection{Outcome}

Measuring the outcome of antitrust cases, I focused on the fate of the antitrust remedy and largely ignored the outcome of the general claim if the case proved to be a counterclaim. The antitrust plaintiff won a claim if both the substantive pleadings and the remedy were confirmed by the court. Partly won refers to outcomes in which, for instance, the judge lowered the amount of damages compared to the initial plea or granted an injunction that did not contain all the points requested. An antitrust action was characterised as being lost if the court did not find a breach of competition law or dismissed the claim. As this study focused on the antitrust problems raised by the 
parties, there might be some proceedings in which the overall outcome for the antitrust plaintiffs was positive although the competition law claim was lost. Only the assertions of antitrust violations are captured in this study. 
Table 3: Outcome of the antitrust claim

\begin{tabular}{|c|c|c|c|c|c|c|c|c|}
\hline & & Won & $\begin{array}{l}\text { Partially } \\
\text { won }\end{array}$ & $\begin{array}{l}\text { Lost or } \\
\text { dismissed }\end{array}$ & Settled + & Other & $\begin{array}{l}\text { Missing } \\
\text { value }\end{array}$ & Total \\
\hline \multirow[t]{2}{*}{$1^{\text {st }}$ instance } & Frequency & 59 & 5 & 108 & 1 & 2 & 5 & 180 \\
\hline & $\%$ of $1^{\text {st }}$ inst & 32.8 & 2.8 & 60 & .6 & 1.1 & 2.8 & 100 \\
\hline \multirow[t]{2}{*}{$1^{\text {st }}$ appeal* } & Frequency & 53 & 9 & 93 & 2 & 1 & 6 & 164 \\
\hline & $\%$ of appeal & 32.3 & 5.5 & 56.7 & 1.2 & .6 & 3.7 & 100 \\
\hline \multirow[t]{2}{*}{ BGH } & Frequency & 11 & . & 13 & . & . & . & 24 \\
\hline & $\%$ of BGH & 45.8 & . & 54.2 & . & . & . & 100 \\
\hline \multirow[t]{2}{*}{ Total } & Frequency & 123 & 14 & 214 & 3 & 3 & 11 & 368 \\
\hline & $\%$ of total & 33.4 & 3.8 & 58.2 & .8 & .8 & 3.0 & 100.0 \\
\hline
\end{tabular}

$* 1^{\text {st }}$ appeal refers to appeals to the higher regional courts excluding appeals on questions of law to the Federal Court of Justice (BGH).

+ Settlements were discovered by chance. Current research indicates that there are more settled antitrust cases.

Parties who brought forward allegations of anticompetitive conduct succeeded or partly succeeded in 37.2 per cent of all proceedings in the sample. The majority of antitrust claims were lost. Settlements were discovered by chance and do not allow any conclusions about the frequency of their occurrence. As settlements are not approved by the court, there is no information about the content of settlements and, therefore, no information about the relative success of the settling parties. Looking at the outcome of counterclaims, it appears that the chance of winning is not much greater than the average for the entire sample. 37.4 per cent of the counterclaims were partly or totally successful and 58.2 per cent lost. ${ }^{147}$ Separating first instance trials from cases decided on the first appeal level, the ratio of won and lost proceedings does not change significantly. In the first instance 60 per cent of the antitrust claims were lost and 35.6

\footnotetext{
${ }^{147}$ See Table 5 in Appendix.
} 
per cent won or partly won. On the appeal stage before the higher regional courts, antitrust plaintiffs (partially) succeeded in 37.8 per cent of all $1^{\text {st }}$ appeal cases and lost 56.7 per cent. Only appeals on questions of law to the Federal Court of Justice (BGH) had a higher chance of success. Plaintiffs won 45.8 per cent and lost 54.2 of their BGH appeals. Bearing in mind that leave to appeal to the Federal Court of Justice has to be granted by the higher regional courts, this probably provides for a screening of potentially unsuccessful or hopeless cases and may, as a consequence, raise the success rate of the appeals that are decided on the merits.

Analysing the data from a law and economic point of view, the ratio of lost and won cases leads to an interesting conclusion about the actual volume of private antitrust litigation. According to Bourjade et al, defendants who have committed an antitrust violation are more likely to settle out of court while those who are innocent are more likely to defend their case bringing the matter to court. ${ }^{148}$ The courts become the place where the innocent proves that he is innocent. ${ }^{149}$ Having discovered many lost cases and assuming that litigants do not overestimate their chances of success and do not commence hopeless legal actions, one could interpret the data as an indicator for a certain level of pre-trial settlement activity. Although the dataset disclosed only three proceedings in which the parties actually settled their dispute, the real number of settlements is presumably higher. ${ }^{150}$ The data does not contain confidential information about in-court or pre-trial settlements so it is hard to estimate the true magnitude of litigation. Looking at the findings of the Georgetown Study, according to which 75 per cent of all US procedures were finally settled, the observed amount of antitrust litigation in Germany seems to be rather the tip of the iceberg than the maximum number of antitrust disputes.

The success rate for the various remedies described in the previous subsection differs greatly as it is shown in Figure 5. Plaintiffs who requested a payback because of a void

\footnotetext{
${ }^{148}$ Bourjade, Rey and Seabright (n 125).

14937.2 per cent of all cases are still won. This could mean that some guilty defendants do not settle or that there is an element of uncertainty about the infringement or causation. It may also hint towards judicial error and judges wrongly acquitting the defendant.

150 That was signalled by practitioners too. See also Rinne and Mühlbach (n 147).
} 
contract, won in more than 50 of the cases. 'Pure' injunctions, not taking into account continuation or conclusion of contracts, proved a relatively successful remedy as well. As for interim relief, the success rate is around 40 per cent. Experience suggests that many requests for interim injunctions are struck down because a decision in favour of the applicant would anticipate a decision on the merits or lacks the urgency required.

Figure 5

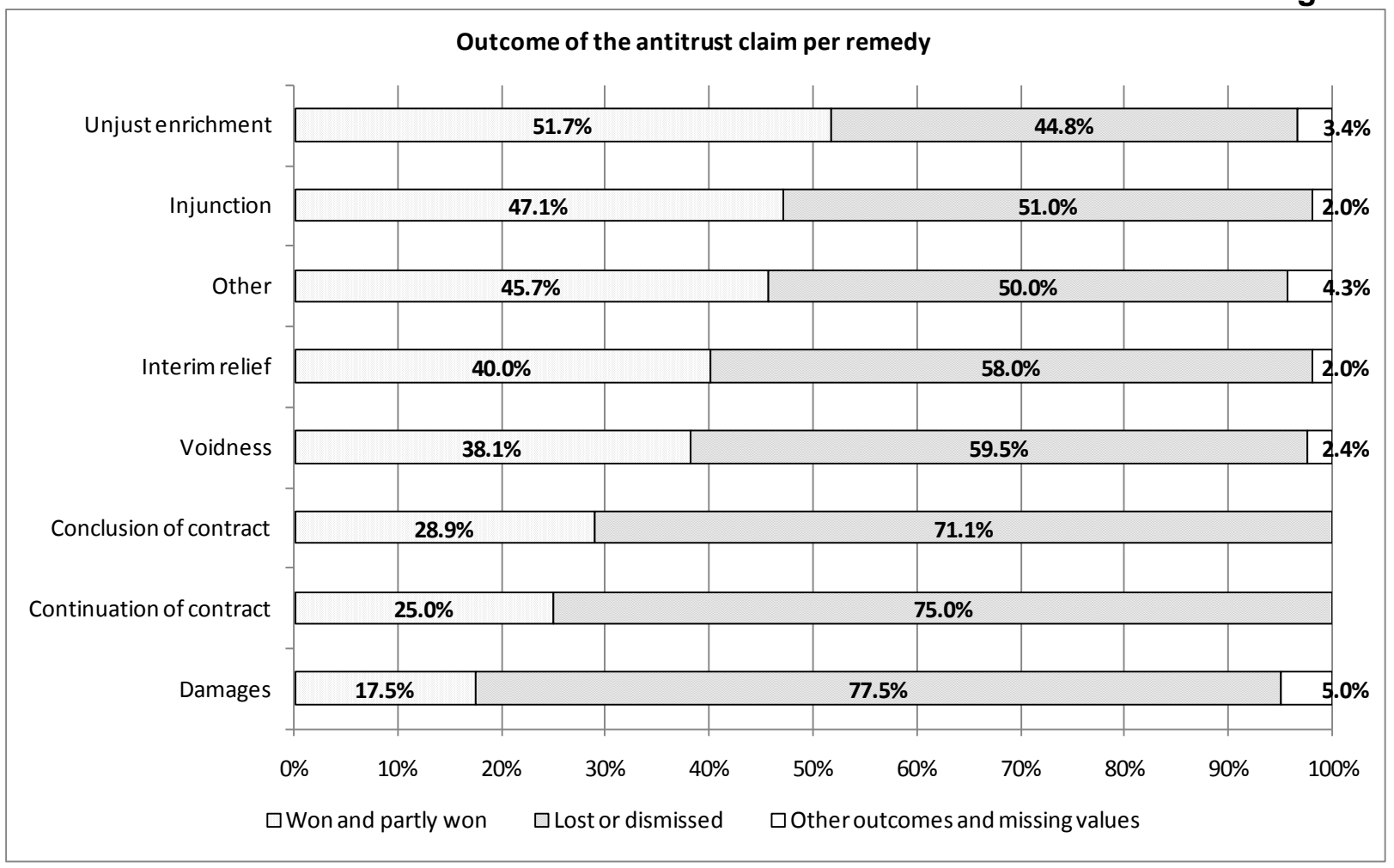

Victims who actually sought compensation for the harm caused by anticompetitive conduct had the lowest chance of success. This may hint towards the intrinsic difficulties of the damages remedies: plaintiffs have to prove just more facts than for all other remedies. This is not a deficit but the nature of compensation claims. On the other hand, one could think that the low success rate proves the existence of obstacles dampening the incentives to request compensation. A third possible explanation for the unfavourable outcome for damages plaintiffs might be a higher settlement rate in 
damages cases which is not captured by my data. From the defendant's point of view, damages claims may present a higher financial risk than requests for injunctions, for instance. The likelihood of higher payments if the trial is lost might induce earlier or more settlements. To prove this point, we would need more information about settled antitrust disputes. The relatively low success rate of damages claims does not allow robust conclusions without a thorough case by case analysis of those actions. Only a qualitative study would reveal the reasons for plaintiffs' failure in each individual case. From the current viewpoint, it would be a fallacy to interpret the low success rate other than as an indicator for more complex litigation. Apart from damages actions, German law provides for another monetary relief that may offset the rather gloomy prospect of compensatory claims. Unjust enrichment requests had the greatest success rate of all remedies and were three times more promising than damages claims. The contrary success rate of unjust enrichment and damages claims, the former is on top in Figure 5 while the latter is at the bottom, will be subject to further investigation. In this context, I will also analyse the relation between contract and antitrust litigation. Since unjust enrichment actions are based on void contracts it poses the question where the boundary between antitrust and contract litigation lies.

\subsection{Statute violation}

The substantive and procedural legal framework for claims against breaches of competition law has been outlined above. ${ }^{151}$ Statutory infringements which were brought forward by antitrust litigants were sorted into four categories reflecting the coarse classification in the FCO's lists of decision. Violations of the antitrust laws could fall under Article 81 (now 101 TFEU), Article 82 (now 102 TFEU), sections 1 to 18 or 19 to 21 ARC. ${ }^{152}$ Article 101 and section 1 ARC prohibit horizontal and vertical agreements between undertakings, decisions by associations of undertakings, and concerted practices which have as their object or effect the prevention, restriction, or distortion of competition. Section 2 ARC contains a provision similar to Article 101(3). Prior to the $7^{\text {th }}$ amendment of the ARC, which came into effect on 1 July 2005, vertical agreements

\footnotetext{
151 See section B.II.

152 To avoid confusion and since no substantive changes to the EU competition law provisions were made with the Treaty of Lisbon, I will refer to the actual numbering of the Articles according to the TFEU.
} 
were not included in section 1 ARC. Like Article 102 section 19 ARC prohibits the abuse of dominance. Unlike EU competition law, section 20 forbids discrimination and unfair hindrance by a non-dominant undertaking if small and medium-sized firms depend on it as suppliers or purchasers (economic dependency). A medium-sized undertaking is dependent if it cannot reasonably switch to other suppliers or purchasers or switching is not sufficiently possible. Due to the lack of data, section 19 and 20 ARC were not distinguished in the study. Section 21 prohibits calls for boycotts against other undertakings and threatening behaviour to induce third parties to carry out actions that are prohibited under the ARC. The category "other" refers to special norms, for instance, in energy and telecommunication sectors or regulations of resale price maintenance for books. The following analysis focuses on the primarily alleged statute violation. 
Table 4: Primarily alleged statute violation

\begin{tabular}{|c|c|c|c|c|}
\hline & & Frequency & $\%$ of EU competition law & $\%$ of total \\
\hline \multirow{3}{*}{$\begin{array}{l}\text { EU } \\
\text { competition } \\
\text { law }\end{array}$} & Art 101 TFEU & 49 & 74.2 & 13.3 \\
\hline & Art 102 TFEU & 17 & 25.8 & 4.6 \\
\hline & Subtotal EU law & 66 & 100 & 17.9 \\
\hline \multirow{7}{*}{$\begin{array}{l}\text { German } \\
\text { competition } \\
\text { law }\end{array}$} & & & $\%$ of German competition la & \\
\hline & Section 1-18 ARC & 71 & 25.1 & 19.3 \\
\hline & Sections 19-21 ARC & 212 & 74.9 & 57.6 \\
\hline & Subtotal German law & 283 & 100 & 76.9 \\
\hline & Other & 18 & . & 4.9 \\
\hline & Missing value & 1 & . & .3 \\
\hline & Total & 368 & . & 100.0 \\
\hline
\end{tabular}

Of 368 primarily alleged statutory violations 212 (57.6 per cent) dealt with unilateral conduct under German law. Horizontal and vertical anticompetitive arrangements violating German antitrust regulations accounted for 19.3 per cent of all cases. Plaintiffs referred to infringements of EU antitrust rules less often: 13.3 per cent asserted an anticompetitive horizontal or vertical agreement while only 4.6 per cent of all cases dealt with the breach of Article 101. Separating cases in which EU law was primarily brought forward from litigation in which plaintiffs alleged a violation of German law shows that the proportion of anticompetitive agreements and unilateral conduct are reversed. Accusations of unilateral conduct dominated antitrust litigation based on German law with 74.9 per cent of German competition law cases. If the claims were based on EU competition law, 74.2 per cent of the antitrust plaintiffs asserted an anticompetitive agreement under Article 101 TFEU. 
Figure 6

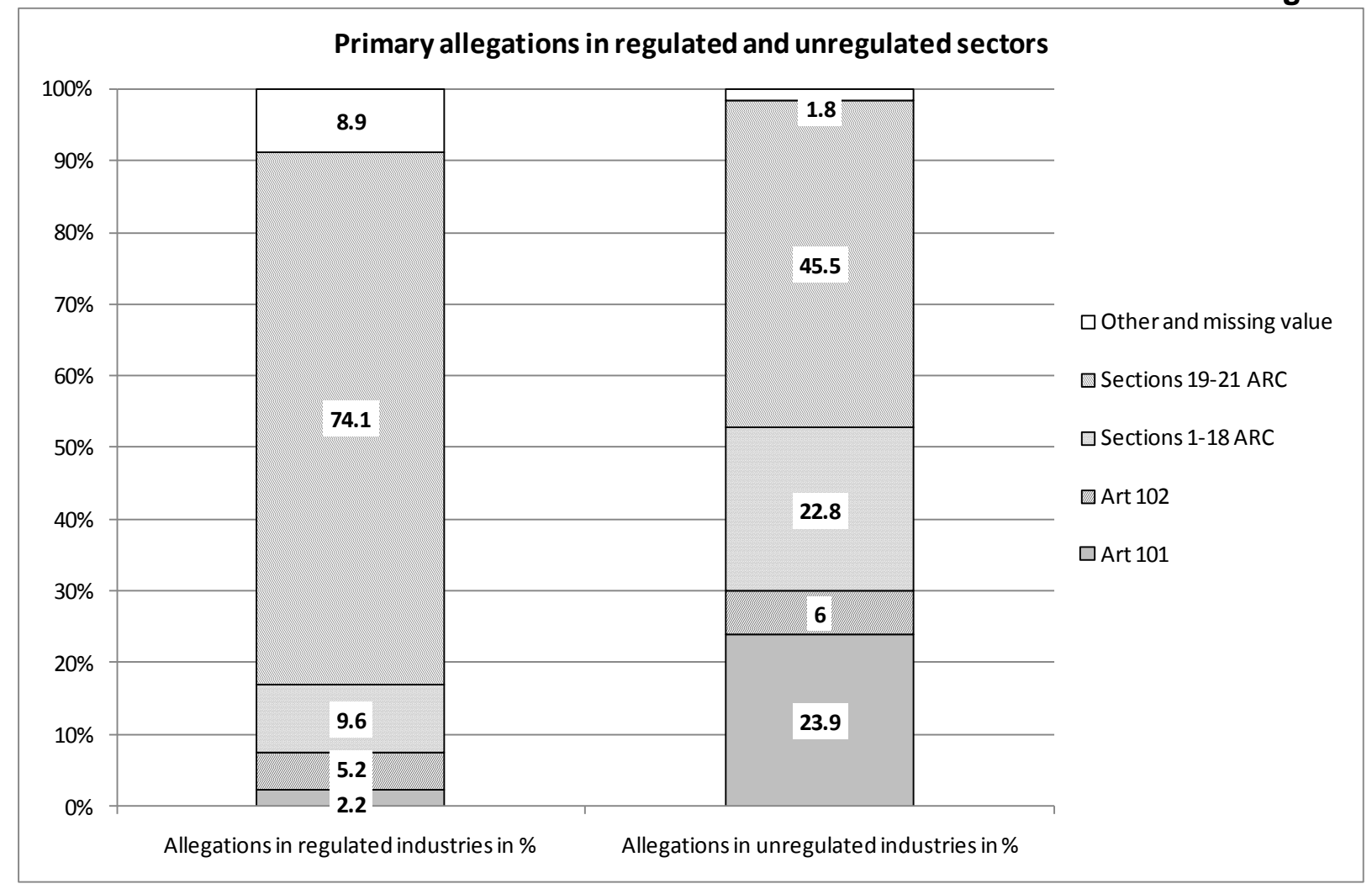

Figure 6 shows the percentage of primary allegations brought in regulated and unregulated industries. Litigation in regulated and partly regulated sectors was mainly founded on unilateral conduct (section 19 to $21 \mathrm{ARC}$ ). Unless most litigation is based on economic dependency according to section 20 ARC - a hypothesis I cannot test with the current dataset - the results indicate that regulated sectors are still characterised by at least one firm enjoying a dominant position. ${ }^{153}$ Litigation in unregulated industries dealt more often with anticompetitive horizontal or vertical agreements. Especially the sharp increase of Article 101 cases from 2.2 per cent in regulated industries to 23.9 per cent in unregulated sectors stands out. A fraction of this litigation goes back to disputes over Regulation 1400/2002 but there also other cases in the wholesale and retail trade sector that contributed to this rise.

\footnotetext{
${ }^{153}$ With the information from this dataset I cannot differentiate between cases in which the claim was based on section 19 (dominance) or on section 20 ARC (relative market power). However, this can and will be tested with new data I have already compiled.
} 
Two points arise from the data presented in this subsection. The first question is why the proportions of unilateral conduct and anticompetitive agreements are reversed if we separate claims based on German law from those relying on EU law. One could think that this was caused by the wider concept of unilateral conduct that underpins German competition law. The discrimination prohibition laid out in section 20 ARC does not require dominance if the victim depends economically on the defendant. Apart from lowering the threshold for antitrust claims, providing the evidence for economic dependency may be easier because information such as data about the supplier relationships and sales data are located in the plaintiff's own sphere. From a potential plaintiff's point of view section 20 ARC lowers the hurdles for antitrust litigation. However, in the absence of precise data it is difficult to reject or confirm this hypothesis. On the other hand, it is claimed that anticompetitive behaviour under section 20 ARC could, as long as it takes place within a contractual relationship, well fit under Article 101. ${ }^{154}$ This may provide another explanation for the reversed ratio of Article 101 and section 1 ARC litigation. If the anticompetitive behaviour affects the trade between Member States, European antitrust law is applied. If the inter-state-trade clause and consequently Article 101 are not applicable, a case might be easier to sustain under section 20 ARC than a claim brought under section 1 ARC. The apparent difference in the enforcement pattern is perhaps not so different in the end if economic dependency allegations can actually be converted into Article 101 accusations. ${ }^{155}$

The second issue originates from the fact that EU competition rules are less often applied than German competition law. At a first glance, the European Commission appears to be right pointing at the underdeveloped private enforcement of the European antitrust law. However, this narrow interpretation may miss the point. Under the Modernisation Regulation 1/2003 the laws of the Member States cannot longer provide for rules that differ from Article 101. Only for the regulation of market power, the Modernisation Regulation permits a deviation of national provisions. Thus, while counting private cases dealing with EU antitrust rules, we also need to take into account

\footnotetext{
${ }^{154}$ Monika Taube, Das Diskriminierungs- und Behinderungsverbot für "relativ marktstarke" Unternehmen: Wettbewerbs- oder individualschützende Funktion des $\S 20$ Abs. 2 GWB (Duncker \& Humblot, Berlin 2006).

${ }^{155}$ Having obtained more precise data on violations of section $20 \mathrm{ARC}, \mathrm{I}$ am currently examining this issue.
} 
litigation that is based on identical national prohibitions. There are several possible reasons why plaintiffs do not bring cases under European law or judges hesitate to apply them. First, the remedies are arranged for by national law. Thus, it does not make a difference for a claim whether it is based on a violation of Article 101 or section 1 ARC, for example. Therefore, claimants and judges may rely on provisions they are more familiar with. Second, if the judge applies Articles 101 or 102, the plaintiff must show that there is an effect on trade between the Member States. This could render procedure more expensive and time-consuming. If there is an equally effective but less costly alternative in the form of national competition law, the plaintiff's choice is not difficult to predict. Third, the differing concepts of the abuse of market power under EU and German law may motivate victims of anticompetitive conduct to focus on national competition law. The concept of unilateral behaviour is said to be broader under the ARC than under Article 102 EC. ${ }^{156}$

\subsection{Anticompetitive behaviour}

Allegations concerning the illegal conduct play a somewhat interesting role in the judges' reasoning. While conducting this survey, it was often difficult to establish the theory of harm or the precise anticompetitive conduct underpinning the antitrust claims. Allegations were phrased in a rather broad way so as to cover several types of anticompetitive conduct. For instance, a plaintiff asserted discriminatory behaviour in very broad terms, so that it would cover unfair pricing but also other discriminatory conduct. Without access to the claimants' statements, I used the broad description of anticompetitive conduct as the basis for my study. Even for cases I traced back and recovered a copy of the decision, the description of the conduct in question was moderate. In the dataset I distinguished 12 types of anticompetitive behaviour in private antitrust proceedings. Table 5 shows the anticompetitive conduct that was primarily claimed starting with Article 101-type behaviour on the top, presenting vertical restraints in the middle and finishing with abuse of market power at the bottom.

\footnotetext{
${ }^{156}$ Wulf-Henning Roth, 'Private Enforcement of European Competition Law - Recommendations Flowing from the German Experience' in Jürgen Basedow (ed), Private Enforcement of EC Competition Law (International competition law series, Kluwer Law International, Alphen a. d. Rijn 2007) 62.
} 
Only a few cases dealt with hard-core cartels. In ten cases allegations of horizontal price fixing were brought forward. Other horizontal agreements included quotas, bid rigging allegations and assertions of anticompetitive non-compete clauses. Noncompete clauses are a routine element of contracts between businesses or shareholders and often turned out to be the reason for the legal dispute. In 19 cases antitrust plaintiffs accused the other side of resale price maintenance. Tying arrangements were less often the source of antitrust litigation with just five cases observed. Other vertical agreements like single branding, export bans, customer allocation, and anticompetitive franchise agreements accounted for 35 cases. As we have already observed above, a considerable number of plaintiffs asked the court to order a conclusion of contract or to continue a contract with the defendant. This is reflected in the number of proceedings that are based on a refusal to deal (60 cases) or an alleged anticompetitive termination of a contract (24 cases). The abuse of dominance or relative market power (economic dependency) accounted for the majority of accusations.

Table 5: Primarily claimed anticompetitive conduct

\begin{tabular}{lcc}
\hline & Frequency & Percent \\
Horizontal price fixing & 11 & 3.0 \\
Other horizontal violations & 25 & 6.8 \\
Resale price maintenance & 19 & 5.2 \\
Tying & 5 & 1.4 \\
Other vertical violations & 35 & 9.5 \\
Exclusive dealing & 14 & 3.8 \\
Termination of contract & 24 & 6.5 \\
Refusal to deal or supply & 60 & 16.3 \\
Excessive pricing & 44 & 12.0 \\
Predatory pricing & 6 & 1.6 \\
Price discrimination & 23 & 6.2 \\
Non-price discrimination & 51 & 13.9 \\
Other & 24 & 6.5 \\
Missing value & 27 & 7.3 \\
Total & 368 & 100.0
\end{tabular}


The number of hard-core cartel cases is very small and comprises of just 3 per cent of all proceedings in this sample despite the importance that is attached to price-fixing allegations in the policy discussion. One potential reason lies within the secrecy of cartels and the difficulties of filing stand-alone actions against them. In the absence of discovery mechanisms or information about the existence of cartels, plaintiffs need a signal and evidence stemming from public investigations. ${ }^{157}$ As we have seen above, the FCO concluded just a few investigations with a formal decision between 2005 and 2007. Hence, plaintiffs either do not learn about an infringement at all or wait (in vain) for a public signal to follow. I already pointed out that the protective scope requirement may have hampered damages actions until 2005. Some argue that other factors such as the lack of representative consumer or class actions or the unclear status of the passing-on defence in Germany cause the small number of cases. ${ }^{158}$

Dividing the cases into regulated and unregulated industries, defendants in regulated industries faced more often than not accusations of unfair or excessive pricing. The data indicate that excessive pricing allegations were particularly frequent in the electricity and gas sector (see Table 4 in Appendix). But also in transportation industries, information and telecommunication markets unfair pricing accounted for the bulk of the claims. The plaintiffs in these three regulated industries also brought actions for the refusal to deal or to supply. Overall, regulated markets tend to have pricing problems or what plaintiffs perceive as such according to my data. These findings are underpinned by various reports of the German Monopoly Commission pointing out that railway networks, telecommunication, postal services and, especially, energy markets suffer from distorted competition. ${ }^{159}$ Whether or not this is a sign of regulatory failure will be subject

\footnotetext{
${ }^{157}$ Even if discovery existed, one could argue that stand-alone actions against cartels are too risky and expensive for victims to bring.

158 ibid. 68.

159 See, for instance, the reports of the German Monopoly Commission: German railway: Monopolkommission, Die Privatisierung der Deutschen Bahn AG: Sondergutachten der Monopolkommission gemäß § 44 Abs. 1 Satz 4 GWB (Bonn 2006) http://www.monopolkommission.de/sg 46/text s46.pdf accessed 03 February 2009; Monopolkommission, Wettbewerbs- und Regulierungsversuche im Eisenbahnverkehr: Sondergutachten der Monopolkommission gemäß § 36 AEG (Bonn 2007) http://www.monopolkommission.de/sg 48/text s48.pdf accessed 03 February 2009. Postal services: Monopolkommission, Telekommunikation und Post 2003: Wettbewerbsintensivierung in der Telekommunikation - Zementierung des Postmonopols: Sondergutachten der Monopolkommission gemäß § 81 Abs. 3 Telekommunikationsgesetz und § 44 Postgesetz (Bonn 2003) http://www.monopolkommission.de/sg 39/text s39.pdf accessed 03 February 2009; Monopolkommission, Wettbewerbsentwicklung bei der Post 2005: Beharren auf alten Privilegien: Sondergutachten der
} 
to further analysis. Anticompetitive conduct violating Article 101 or sections 1-18 ARC occurred more often in unregulated sectors.

Figure 7

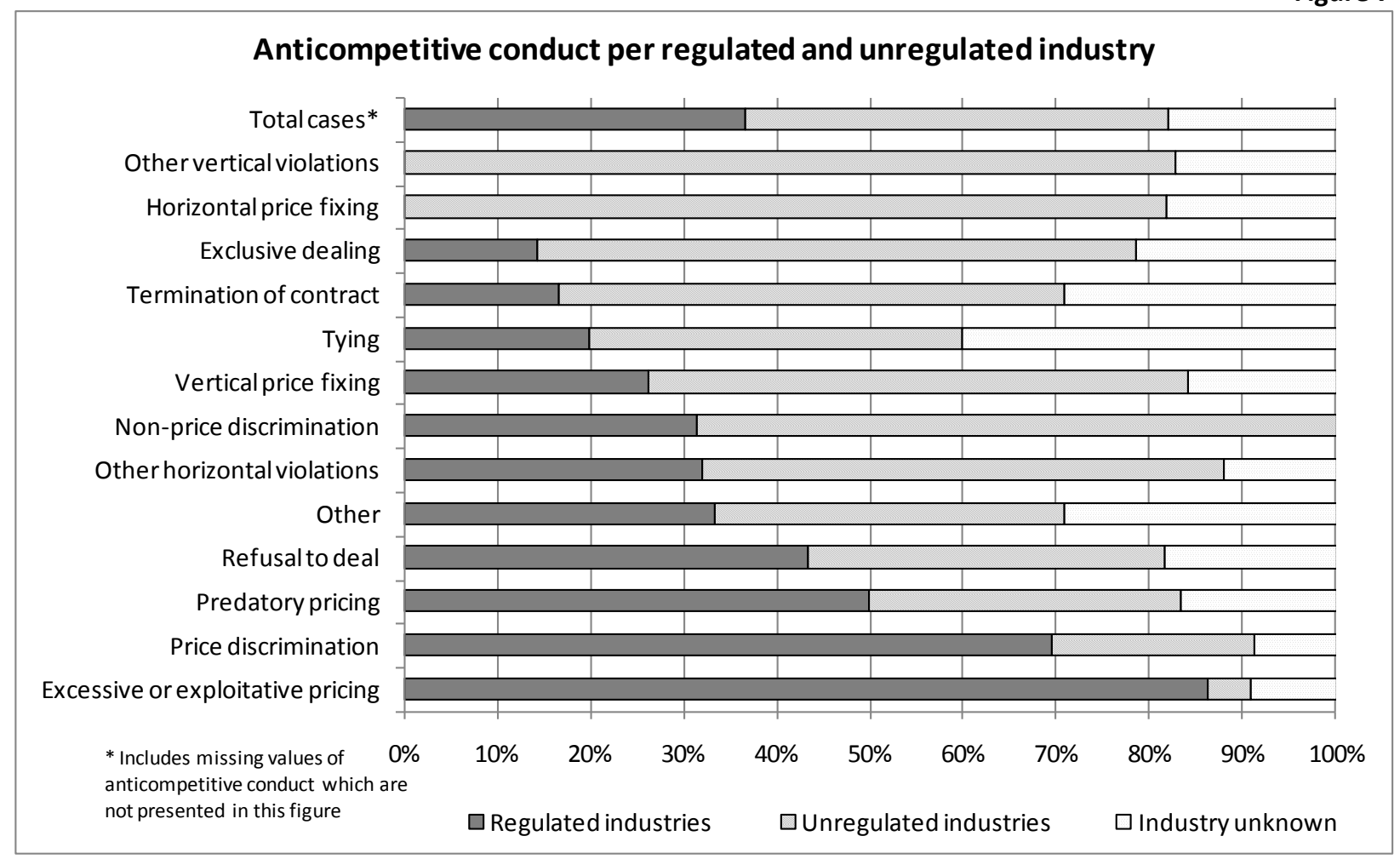

The high ratio of disputes in vertical relationships and against dominant firms for unfair pricing and other discriminatory conduct raises concerns with regard to contract litigation. Obviously, plaintiffs who were part of the contract with the infringer face fewer

Monopolkommission gemäß § 44 Postgesetz in Verbindung mit § 81 Telekommunikationsgesetz a.F. (Bonn 2005) http://www.monopolkommission.de/sg 44/text s44.pdf accessed 03 February 2009; Monopolkommission, Wettbewerbsentwicklung bei der Post 2007: Monopolkampf mit allen Mitteln: Sondergutachten gemäß § 44 Postgesetz in Verbindung mit § 81 Abs. 3 Telekommunikationsgesetz 1996 (Bonn 2007) http://www.monopolkommission.de/sg 51/text s51.pdf accessed 03 February 2009. Energy: Monopolkommission, Strom und Gas 2007: Wettbewerbsdefizite und zögerliche Regulierung: Sondergutachten der Monopolkommission gemäß § 62 Abs. 1 des Energiewirtschaftsgesetzes (Bonn 2007)

http://www.monopolkommission.de/sg 49/text s49.pdf accessed 03 February 2009. Telecommunications: Monopolkommission, Wettbewerbsentwicklung bei der Telekommunikation 2005: Dynamik unter neuen Rahmenbedingungen: Sondergutachten der Monopolkommission gemäß § 121 Telekommunikationsgesetz (Bonn 2005) http://www.monopolkommission.de/sg 43/text s43.pdf accessed 03 February 2009. 
difficulties in gathering evidence or discovering the infringement in the first place. ${ }^{160}$ During the data gathering it became apparent that the antitrust issue was often accompanied by a contract law issue dispute or that antitrust violation was an annex to the contract claim. Due to the fact that I excluded cases from my sample in which the antitrust issues could not be clarified, it is likely that even more of these contract disputes exist. Walter van Gerven characterised this type of contractual litigation being the rather typical case of private antitrust enforcement. ${ }^{161}$

\subsection{Length of trial}

When faced with the decision of whether or not to bring a dispute before court, the estimated length of the proceedings is a factor likely to influence the parties' decision. The prospect of several years of dispute before a final decision is handed down will deter requests for redress of losses or other remediation. Court procedures that take a long time increase the legal cost for both plaintiffs and defendants and may force economically weaker plaintiffs or defendants to prematurely settle the case. As for the duration of antitrust cases in Germany, there are some limitations in calculating the length of proceedings. Although the exact date of the decision is known for 365 cases out of 368 there is no publicly available information about the starting date. Only access to the strictly confidential court records would reveal the precise date on which the plaintiffs commenced their legal action. However, the record number of each decision contains the year in which a proceeding was initiated in a particular instance. Unfortunately, it does not indicate when the case as a whole was commenced because cases are assigned a new record number in each instance. As long as a case ended in the first instance with a decision of a regional court, the length of the proceeding in this instance equaled the duration of the whole case. If cases were appealed to the higher regional courts or the Federal Court of Justice, the data only tell us about the time period the case needed in a particular appeal instance. In order to determine a proxy for the length of a proceeding before a given court I assumed that each case started at the

\footnotetext{
${ }^{160}$ Roth (n 157) 67. See section 19 ARC.

${ }^{161}$ Walter van Gerven, 'Private Enforcement of EC Competition Rules in the ECJ - Courage v. Crehan and the Way Ahead' in Jürgen Basedow (ed), Private Enforcement of EC Competition Law (International competition law series, Kluwer Law International, Alphen a. d. Rijn 2007) 19.
} 
beginning of the year indicated in the record number. This is probably too conservative a measure and will exaggerate the time span litigants spent in a given instance.

Figure 8

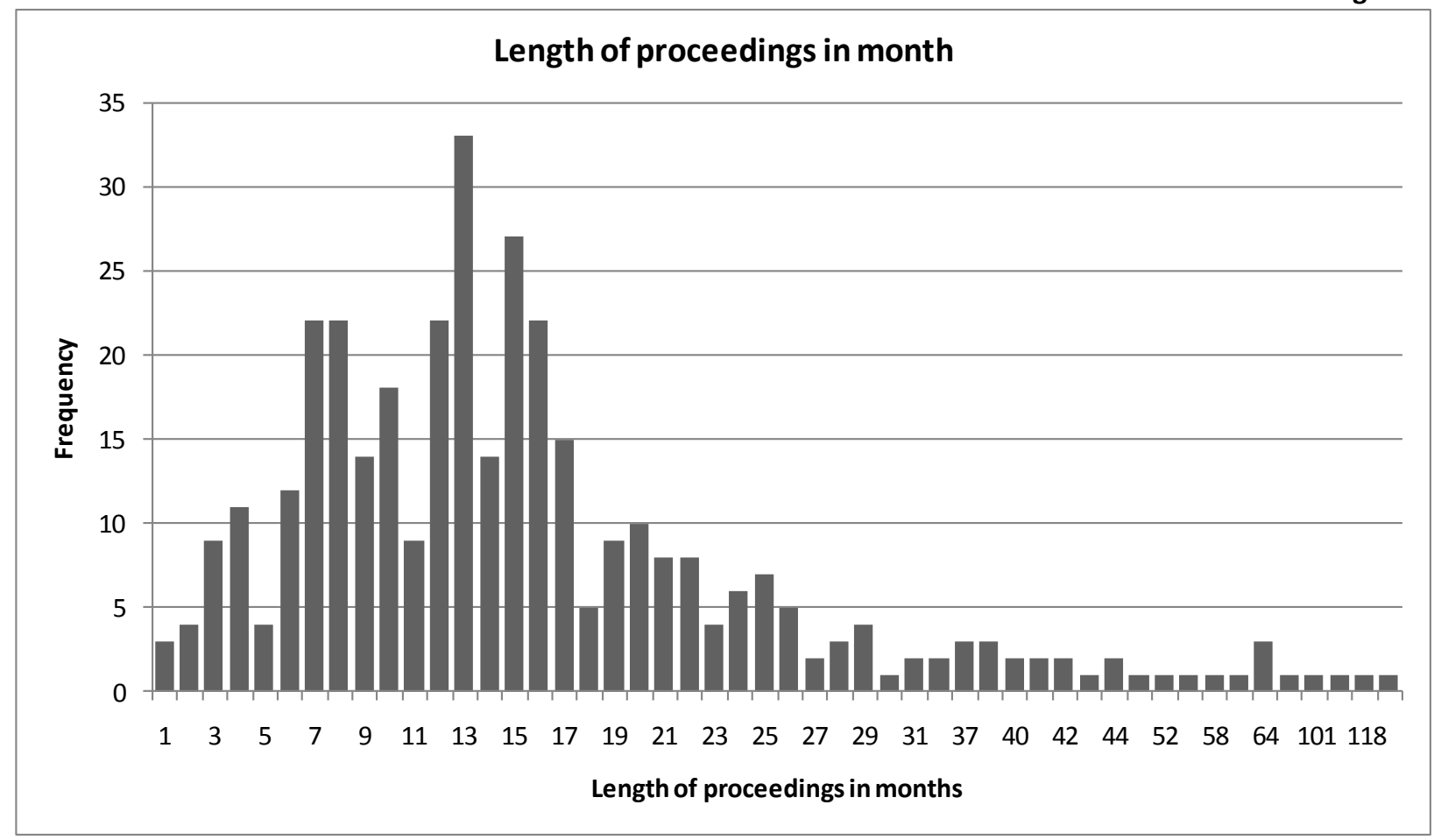

The minimum time parties spent in court was one month while the maximum time span amounted to 175 months in one proceeding. On average, courts handed down their decisions after 17.01 months. Looking at the different remedies, the courts needed very little time in interim proceedings. Requests for interim relief were answered in 8.4 months while a decision on damages needed 28.98 months on average (40 observations). Experience suggests that interim proceedings take less time and the estimated time period exaggerates the actual length. The histogram in Figure 8 shows us the distribution of the length of proceedings in months. Courts concluded the majority of cases in a give instance within 2 years. But we also observe several outliers with the longest proceedings lasting for 175 months which is more than 14 years. Of the four cases that last longer than 100 months three dealt with damages and one with a 
voidness request. Ignoring those particularly long-lasting proceedings, the mean length of the proceedings for damages claims drops to 20.73 month (based on 37 decisions instead of 40). This is not far off from injunctions which needed 19.25 months to be finally decided. The 84 voidness assertions in the sample were dealt with within 17.51 months (or 16.3 if the one proceeding that lasted more than 100 months is not taken into account). As for the remaining remedies, the continuation of contracts needed 16.25 months per instance, conclusion of contract requests required only 11.84 and unjust enrichment claims were dealt with in 18.14 months. Other claims lasted 16.49 months per instance.

Although the method of estimating the length of antitrust litigation suffers from several flaws it provides the best proxy we can establish given the data. Not surprisingly, damages procedures tend to last longer than other remedies. The data confirms that interim relief was granted in much less time than other remedies. By contrast, injunctions or unjust enrichment claims required more time until judges handed down their decisions on the merits. The results of this estimation as well as extensions, for instance, with respect to the length of follow-on and stand-alone claims will be tested with the new dataset as it also contains the precise start date for some cases.

\section{Conclusions}

Numerous contributions in Europe and Germany have dealt with the legal aspects of private antitrust enforcement. Many observers claim that private antitrust actions have been in a dire state in both Europe and Germany. However, looking at private antitrust enforcement in Germany, the empirical basis for those claims is weak. Private litigation for the violation of German and European competition law is widespread and manifold in shape. The contrast between my findings and the dominant notion in the literature is best exemplified with a statement from the German Monopoly Commission, an advising body of lawyers and economists, from 2001:

"The Monopolies Commission wishes to affirm the doubts it has already expressed that a system that is largely based on litigation on private initiative can offer a suitable substitute for protection 
of competition largely by authorities. [...] Moreover, companies in continental European member states are still very reluctant to claim damages for restrictive practices and agreements. It can be pointed out that so far there have been virtually no cases of this kind, and their practical importance can generally be regarded as marginal." 162

Although the comment stems from 2001 while my study covers the years 2005 to 2007 it is unlikely that the number of private antitrust cases increased dramatically within four years. More important though is that the statement points towards a misconception of private antitrust enforcement.

Private actions are often reduced to damages litigation for the violation of EU competition law. With such a narrow focus, the European Commission rightly points out that there are not many cases even with respect to Germany. However, to conclude that private actions do not exist or do not play a role in the overall enforcement scheme jumps the gun. My data have shown that parties employed various remedies including unjust enrichment requests and injunctions in order to pursue a breach of the competition rules. Private enforcement rather supplements public enforcement picking up infringements that have less impact on the economy as a whole instead of duplicating public investigations into hard-core violations. For example, plaintiffs initiated proceedings against dominant firms which were not investigated by the competition authorities due to disproportionate cost or insignificant impact on the economy as a whole. It may be wrong to assume that private parties will take on hard-core violations in the first place. Thus, the question is which types of infringement private enforcers are supposed to pursue. Should they aim at hard-core violations? Or is it sufficient if antitrust plaintiffs complement public enforcement targeting "softer" infringements?

My data have also shown that in many instances private cases are closely related to contract disputes. Contract cases are met with suspicion in US antitrust law because it is thought that they are used to exploit defendants and distort competition law by means of the treble damages award. However, this concern only holds if the rules under which

\footnotetext{
162 Monopolkommission, Folgeprobleme der europäischen Kartellverfahrensreform: Sondergutachten der Monopolkommission gemäß § 44 Abs. 1 Satz 4 GWB (Bonn 2001) 66.
} 
antitrust cases are litigated differ from those for contracts. As there are generally no special rules for antitrust claims in Germany, antitrust litigation in contract relationships may not be such a worrying problem after all. This will certainly change if special rules for damages actions for the violation of EU competition law are created as suggested by the European Commission. ${ }^{163}$

As for the application of EU competition law, we have seen that plaintiffs were rather reluctant to base their claims on Articles 101 or 102 . However, if private enforcers pick up infringements that are on smaller scale, it is doubtful that those cases meet the interstate trade criterion in the first place. Taking into account that most national antitrust provisions resemble European competition law rules, the application of national or European competition law may not make a huge difference.

The question that remains unanswered is why we observe many cases despite the lack of class actions, contingency fee agreements or damages multipliers which drive litigation in the United States. I would suspect that the low and, maybe, predictable litigation cost provide for lower litigation barriers and, thus, motivate plaintiffs to bring their disputes to the court. The absence of costly discovery would argue in the same vein. One could also assert that Germany is characterised by a litigation culture in which victims of anticompetitive behaviour refer to the courts to remediate their harm. After all, my research indicates that we missed some important points in the discussion about the strengthening of private enforcement.

The observations and questions from this empirical work were incorporated in a second study on private antitrust litigation in Germany. The analysis of this broader and more precise dataset is currently under way. But even without new data, two points emerged that will be addressed separately. First, the data showed that plaintiffs were hesitant to resort to damages actions. This raises the question whether damages claims should be strengthened and, if so, how. The damages actions reform initiated by the European

\footnotetext{
${ }^{163}$ Why only antitrust damages actions should be strengthened, in contrast to other areas of law, is another question that has not been answered yet.
} 
Commission provides for a starting point but needs to be assessed in the light of the new data. ${ }^{164}$ Second, we have observed that injunctions are widely and successfully used in antitrust cases in Germany. What the data could not tell is why they are so important and dominant. This will be the guiding question for yet another research project.

Overall, the nature of private actions in Germany and, maybe, in Europe has been misjudged. It seems that there are many situations in which injunctions or interim relief satisfy the plaintiff without the need for compensation. Consequently, the question German and European legislators have to ask is what type of private enforcement system they want and on which assumptions potential legislative measures will be based. The complete underdevelopment of all private actions in Germany and, consequently, in Europe is certainly a myth.

${ }^{164}$ Sebastian Peyer, "(Cartel)members only - Revisiting Private Antitrust Policy in Europe". 


\section{Appendix}

\begin{tabular}{ccc} 
Table1 & Private antitrust cases per federal state & \\
\hline Federal state & Frequency & Percent \\
Baden-Württemberg & 27 & 7.3 \\
Bavaria & 60 & 16.3 \\
Berlin & 14 & 3.8 \\
Brandenburg & 6 & 1.6 \\
Bremen & 2 & .5 \\
Hamburg & 7 & 1.9 \\
Hesse & 36 & 9.8 \\
Lower Saxony & 8 & 2.2 \\
North Rhine-Westphalia & 153 & 41.6 \\
Rhineland-Palatinate & 8 & 2.2 \\
Saxony & 7 & 1.9 \\
Saxony-Anhalt & 1 & .3 \\
Schleswig-Holstein & 11 & 3.0 \\
Thuringia & 4 & 1.1 \\
BGH* & 24 & 6.5 \\
Total & 368 & 100.0 \\
\hline
\end{tabular}

* The BGH is a Federal court and has its seat in Karlsruhe

† There are two Federal States missing for which no cases were reported: Mecklenburg-Vorpommern and Saarland. 
Table 2: Crosstabulation of industry and business relationship

\begin{tabular}{|c|c|c|c|c|c|c|c|}
\hline & & \multicolumn{6}{|c|}{ Party who claims antitrust violation is... } \\
\hline & & Competitor & $\begin{array}{l}\text { Dealer or } \\
\text { supplier }\end{array}$ & Customer & $\begin{array}{c}\text { Final } \\
\text { customer }\end{array}$ & Other* & Total \\
\hline \multirow[t]{2}{*}{ Manufacturing } & Count & 4 & 2 & 14 & 0 & 6 & 26 \\
\hline & $\%$ within Industry & 15.4 & 7.7 & 53.8 & .0 & 22.9 & 100.0 \\
\hline \multirow{2}{*}{$\begin{array}{l}\text { Electricity, gas, steam, air } \\
\text { conditioning }\end{array}$} & Count & 5 & 2 & 36 & 1 & 3 & 47 \\
\hline & $\%$ within Industry & 10.6 & 4.3 & 76.6 & 2.1 & 6.4 & 100.0 \\
\hline \multirow{2}{*}{$\begin{array}{l}\text { Water, sewerage, waste, } \\
\text { remediation }\end{array}$} & Count & 1 & 0 & 4 & 0 & 0 & 5 \\
\hline & $\%$ within Industry & 20.0 & .0 & 80.0 & .0 & .0 & 100.0 \\
\hline \multirow[t]{2}{*}{ Construction } & Count & 5 & 1 & 4 & 0 & 1 & 11 \\
\hline & $\%$ within Industry & 45.5 & 9.1 & 36.4 & .0 & 9.1 & 100.0 \\
\hline \multirow[t]{2}{*}{ Wholesale, retail trade } & Count & 6 & 3 & 48 & 0 & 17 & 74 \\
\hline & $\%$ within Industry & 8.1 & 4.1 & 64.9 & .0 & 23.1 & 100.0 \\
\hline \multirow{2}{*}{$\begin{array}{l}\text { Accommodation and food } \\
\text { service }\end{array}$} & Count & 0 & 0 & 5 & 0 & 5 & 10 \\
\hline & $\%$ within Industry & .0 & .0 & 50.0 & .0 & 50.0 & 100.0 \\
\hline \multirow[t]{2}{*}{ Transport and storage } & Count & 12 & 0 & 23 & 0 & 4 & 39 \\
\hline & $\%$ within Industry & 30.8 & .0 & 59.0 & .0 & 10.3 & 100.0 \\
\hline \multirow{4}{*}{$\begin{array}{l}\text { Information and } \\
\text { communication } \\
\text { Financial and insurance }\end{array}$} & Count & 21 & 1 & 18 & 0 & 4 & 44 \\
\hline & $\%$ within Industry & 47.7 & 2.3 & 40.9 & .0 & 9.1 & 100.0 \\
\hline & Count & 1 & 0 & 4 & 0 & 0 & 5 \\
\hline & $\%$ within Industry & 20.0 & .0 & 80.0 & .0 & .0 & 100.0 \\
\hline \multirow{2}{*}{$\begin{array}{l}\text { Professional, scientific, } \\
\text { technical activities }\end{array}$} & Count & 1 & 0 & 0 & 0 & 0 & 1 \\
\hline & $\%$ within Industry & 100.0 & .0 & .0 & .0 & .0 & 100.0 \\
\hline \multirow{2}{*}{$\begin{array}{l}\text { Administrative and } \\
\text { support service }\end{array}$} & Count & 1 & 0 & 10 & 0 & 3 & 14 \\
\hline & $\%$ within Industry & 7.1 & .0 & 71.4 & .0 & 21.3 & 100.0 \\
\hline \multirow[t]{2}{*}{ Human health, social work } & Count & 1 & 0 & 2 & 0 & 0 & 3 \\
\hline & $\%$ within Industry & 33.3 & .0 & 66.7 & .0 & .0 & 100.0 \\
\hline \multirow{2}{*}{$\begin{array}{l}\text { Arts, entertainment and } \\
\text { recreation }\end{array}$} & Count & 2 & 1 & 11 & 0 & 7 & 21 \\
\hline & $\%$ within Industry & 9.5 & 4.8 & 52.4 & .0 & 33.3 & 100.0 \\
\hline \multirow[t]{2}{*}{ Other service activities } & Count & 0 & 0 & 2 & 0 & 0 & 2 \\
\hline & $\%$ within Industry & .0 & .0 & 100.0 & .0 & .0 & 100.0 \\
\hline \multirow[t]{2}{*}{ Missing value } & Count & 5 & 2 & 31 & 0 & 28 & 66 \\
\hline & $\%$ within Industry & 7.6 & 3.0 & 47.0 & .0 & 42.4 & 100.0 \\
\hline \multirow[t]{2}{*}{ Total } & Count & 65 & 12 & 212 & 1 & 88 & 368 \\
\hline & $\%$ within Industry & 17.7 & 3.3 & 57.6 & .3 & 21.2 & 100.0 \\
\hline
\end{tabular}

*Other includes franchisees, licensees. indirect purchasers and missing values 


\begin{tabular}{|c|c|c|c|c|c|c|c|c|c|c|}
\hline & & & Party & ho $\mathrm{c}$ & $\mathrm{ms}$ a & itru & violati & $n$ is. & & \\
\hline & $\begin{array}{l}\stackrel{0}{0} \\
3 \\
0 \\
0 \\
0 \\
\stackrel{+}{+} \\
\stackrel{0}{0}\end{array}$ & 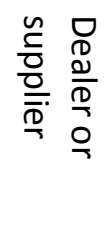 & $\begin{array}{l}\frac{0}{1} \\
\frac{1}{n} \\
0 \\
\frac{0}{3} \\
\frac{0}{1}\end{array}$ & 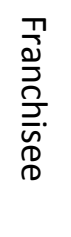 & $\begin{array}{l}\frac{\bar{C}}{\bar{D}} \\
\stackrel{D}{\bar{D}} \\
\stackrel{D}{D}\end{array}$ & 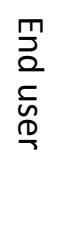 & 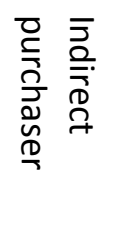 & $\begin{array}{l}\stackrel{0}{+} \\
\stackrel{+}{\mathbb{D}} \\
\stackrel{n}{n}\end{array}$ & 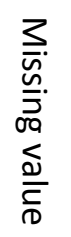 & $\begin{array}{l}-1 \\
\underline{0} \\
\underline{\Phi}\end{array}$ \\
\hline Damages & 1 & 1 & 20 & 5 & 1 & 0 & 1 & 1 & 10 & 40 \\
\hline Injunction & 13 & 3 & 23 & 1 & 3 & 0 & 0 & 1 & 7 & 51 \\
\hline Voidness & 23 & 4 & 39 & 6 & 8 & 0 & 0 & 0 & 4 & 84 \\
\hline Interim relief & 16 & 1 & 24 & 1 & 0 & 1 & 0 & 1 & 6 & 50 \\
\hline Other & 6 & 2 & 34 & 1 & 0 & 0 & 0 & 0 & 3 & 46 \\
\hline Continuation of contract & 0 & 1 & 11 & 1 & 1 & 0 & 0 & 1 & 1 & 16 \\
\hline Conclusion of contract & 1 & 0 & 33 & 0 & 0 & 0 & 0 & 2 & 2 & 38 \\
\hline Unjust enrichment & 3 & 0 & 21 & 3 & 0 & 0 & 0 & 0 & 2 & 29 \\
\hline Missing value & 2 & 0 & 7 & 0 & 1 & 0 & 0 & 0 & 4 & 14 \\
\hline Total & 65 & 12 & 212 & 18 & 14 & 1 & 1 & 6 & 39 & 368 \\
\hline
\end{tabular}


Table 4: Crosstabulation of primarily alleged anticompetitive conduct and industry

\begin{tabular}{|c|c|c|c|c|c|c|c|c|c|c|c|c|c|c|c|}
\hline & 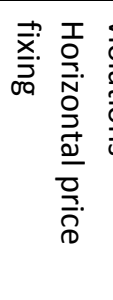 & 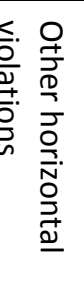 & 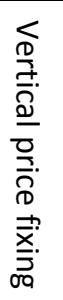 & ફ. & 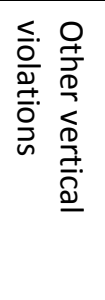 & 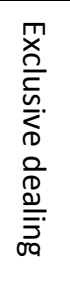 & 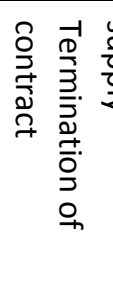 & 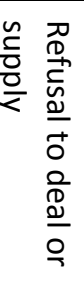 & 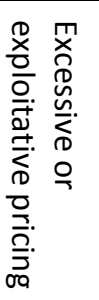 & 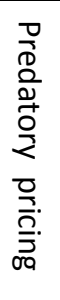 & 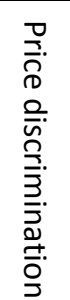 & 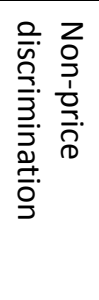 & 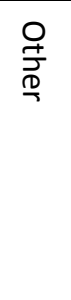 & 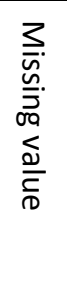 & $\begin{array}{l}\overrightarrow{1} \\
\underline{\underline{\Phi}} \\
\underline{0}\end{array}$ \\
\hline Manufacturing & 4 & 2 & 0 & 0 & 4 & 1 & 1 & 2 & 0 & 0 & 0 & 11 & 1 & 0 & 26 \\
\hline $\begin{array}{l}\text { Electricity, gas, } \\
\text { steam, air } \\
\text { conditioning } \\
\text { Water. }\end{array}$ & 0 & 1 & 1 & 0 & 0 & 1 & 3 & 8 & 20 & 0 & 6 & 1 & 4 & 2 & 47 \\
\hline $\begin{array}{l}\text { sewerage, waste } \\
\text { and remediation }\end{array}$ & 0 & 1 & 2 & 0 & 0 & 0 & 0 & 0 & 1 & 0 & 0 & 1 & 0 & 0 & 5 \\
\hline Construction & 5 & 1 & 0 & 0 & 0 & 0 & 0 & 0 & 0 & 0 & 0 & 4 & 1 & 0 & 11 \\
\hline $\begin{array}{l}\text { Wholesale and } \\
\text { retail trade; } \\
\text { repair of motor } \\
\text { vehicles }\end{array}$ & 0 & 6 & 8 & 2 & 20 & 5 & 5 & 12 & 1 & 0 & 2 & 8 & 3 & 2 & 74 \\
\hline $\begin{array}{l}\text { Accommodation } \\
\text { and food service }\end{array}$ & 0 & 0 & 2 & 0 & 4 & 3 & 1 & 0 & 0 & 0 & 0 & 0 & 0 & 0 & 10 \\
\hline $\begin{array}{l}\text { Transport and } \\
\text { storage }\end{array}$ & 0 & 2 & 0 & 0 & 0 & 0 & 0 & 9 & 9 & 1 & 8 & 5 & 2 & 3 & 39 \\
\hline $\begin{array}{l}\text { Information and } \\
\text { communication }\end{array}$ & 0 & 4 & 2 & 1 & 0 & 1 & 1 & 9 & 8 & 2 & 2 & 9 & 2 & 3 & 44 \\
\hline $\begin{array}{l}\text { Financial and } \\
\text { insurance } \\
\text { Professional, }\end{array}$ & 0 & 1 & 0 & 0 & 0 & 0 & 1 & 0 & 0 & 1 & 0 & 1 & 0 & 1 & 5 \\
\hline $\begin{array}{l}\text { scientific, } \\
\text { technical } \\
\text { activities }\end{array}$ & 0 & 0 & 0 & 0 & 0 & 0 & 0 & 0 & 0 & 0 & 0 & 1 & 0 & 0 & 1 \\
\hline $\begin{array}{l}\text { Administrative } \\
\text { support services }\end{array}$ & 0 & 0 & 1 & 0 & 1 & 0 & 1 & 5 & 0 & 1 & 0 & 4 & 1 & 0 & 14 \\
\hline $\begin{array}{l}\text { Human health } \\
\text { and social work }\end{array}$ & 0 & 1 & 0 & 0 & 0 & 0 & 0 & 0 & 0 & 0 & 0 & 2 & 0 & 0 & 3 \\
\hline $\begin{array}{l}\text { Arts, recreation, } \\
\text { entertainment }\end{array}$ & 0 & 3 & 0 & 0 & 0 & 0 & 4 & 3 & 1 & 0 & 3 & 3 & 3 & 1 & 21 \\
\hline Other services & 0 & 0 & 0 & 0 & 0 & 0 & 0 & 1 & 0 & 0 & 0 & 1 & 0 & 0 & 2 \\
\hline Missing value & 2 & 3 & 3 & 2 & 6 & 3 & 7 & 11 & 4 & 1 & 2 & 0 & 7 & 15 & 66 \\
\hline Total & 11 & 25 & 19 & 5 & 35 & 14 & 24 & 60 & 44 & 6 & 23 & 51 & 24 & 27 & 368 \\
\hline
\end{tabular}


Table 5: Outcome of antitrust counterclaims

\begin{tabular}{lccc}
\hline & Number & Percent & Cumulative Percent \\
Won & 32 & 35.2 & 35.2 \\
Partially won & 2 & 2.2 & 37.4 \\
Lost/Dismissed & 53 & 58.2 & 95.6 \\
Settled & 3 & 3.3 & 98.9 \\
Missing value & 1 & 1.1 & 100.0 \\
Total & 91 & 100.0 &
\end{tabular}

